\title{
Combined effect of waste glass powder and recycled steel fibers on mechanical behavior of concrete
}

\author{
Mavoori Hitesh Kumar ${ }^{1} \cdot$ Nihar Ranjan Mohanta $^{1} \cdot$ Sandeep Samantaray ${ }^{2} \cdot$ Nagarampalli Manoj Kumar $^{1}$
}

Received: 24 May 2020 / Accepted: 9 February 2021 / Published online: 19 February 2021

(c) The Author(s) 2021, corrected publication 2021 OPEN

\begin{abstract}
Several attempts upon inclusion of industrial waste materials such as fly ash, silica fume, GGBS, metakaolin and copper slag in concrete have already been experimented that exerted a significant impact on concrete with enhanced mechanical and improved durability properties. There were numerous authentic researches that reported the significance of steel fibers in strengthening the flexural property of concrete. The paper investigates the combined effect of waste glass powder (WGP) that has been utilized as a substitution for fine aggregate in varying percentages of $0 \%, 3 \%, 6 \%, 9 \%, 12 \%$ and $15 \%$ and further reinforcing it with recycled steel fibers (RSF), drawn from waste tires by volume of concrete. WGP was used as $0 \%, 3 \%, 6 \%, 9 \%, 12 \%, 15 \%$ by mass replacement of fine aggregate with four different volume fractions of recycled steel fiber (i.e., 0, 0.5, 1 and 1.5\%), respectively. All proportions of concrete mixes were investigated to study the variations in compressive, flexural and split tensile strength with varied replacements levels of WGP along with various fractions of RSF for 7 and 28 days curing. A mix of $9 \%$ WGP exhibited the maximum compressive, flexural and split tensile strength. It was found that mechanical properties of concrete rose up to $9 \%$ replacement level of WGP and later declined. Also it was confirmed that increase in the amount of RSF further boosted the compressive and flexural behavior of concrete. Overall, an optimum concrete mix with $9 \%$ replacement of WGP, reinforced with $1 \%$ inclusion of RSF, reported the best performance compared to other mixes.
\end{abstract}

Keywords Waste glass powder (WGP) · Recycled steel fibers (RSF) - Compressive strength · Flexural strength · Split tensile strength

\section{Introduction}

Construction industry has become one of the wide areas of research, particularly in the field of concrete technology. Nowadays, the need for basic infrastructure in the urban areas led to the increase in developmental activities throughout the globe for which there is huge demand for concrete, posing a major threat to the environment due to emission of higher levels of greenhouse gases such as carbon dioxide. The practice of incorporating the industrial waste materials has gained tremendous attention in the field of research to develop greener and sustainable building materials. In India, more than 300 tons of waste glass is disposed daily in the form of glass bottle from beverage factories and in the form of glass sheet from ceramics industries. Disposal of huge quantity of glass as waste is a serious threat to the environment. To bring out the solution for this, since past ten years many recycling methods were adopted to reuse the waste glass again. Similarly, waste glass is considered as a key element for further research in the field of construction industry, which can also be incorporated in the concrete to examine the

$\triangle$ Nihar Ranjan Mohanta, niharthenew@gmail.com; Mavoori Hitesh Kumar, Kumar.hitesh646@gmail.com; Sandeep Samantaray, sandeep1139_rs@civil.nits.ac.in; Nagarampalli Manoj Kumar, manojnagarampalli@giet.edu | ${ }^{1}$ GIET University, Gunupur, India. ${ }^{2}$ NIT, Silchar, Assam, India. 
changes in the mechanical properties of concrete. Owing to the presence of higher quantity of silica as a major component in glass, it was proposed to replace sand with fine glass powder in varied proportions to examine its effect on strength behavior of concrete in the present paper.

Waste tires also constitute major amount of solid waste throughout India, where it has been reported that nearly 760 million tires are coming out as waste commonly from vehicle mechanic repair sheds and automobile industries every year. Waste tires are nowadays recycled to extract few raw materials that can be incorporated in concrete to enhance its strength properties like steel fibers, rubber fibers and rubber powder. Hence, waste tires were collected from the nearby mechanic repair sheds and were processed to obtain recycled steel fibers which are used in the present paper.

Lot of research works was carried out previously to analyze the true behavior of glass powder and recycled steel fibers in concrete. Here are few reviews stated below. Simalti et al. [1] attempted their vast research in examining the strength and durability of concrete reinforced with recycled steel fibers (RSF) drawn from waste tires and manufactured steel fibers (MSF), respectively, in varying amounts of $0 \%, 0.5 \%, 1 \%$ and $1.5 \%$. It was reported that the concrete mix reinforced with $1.5 \%$ RSF exhibited the best performance in all aspects compared to MSF. Isa et al. [2] aimed to produce affordable and ecofriendly ultra-high performance concrete (UHPC) by including recycled tire steel fibers (RTSF) and recycled tire steel chords (RTSC) in higher amounts of $2 \%, 3 \%$ and $4 \%$. It was resulted that the higher amount of RTSF and RTSC reduced the flexural strength significantly that clearly implies to incorporate lower amounts of steel fibers to enhance strength. Also, the investigation proved that the concrete mixes with RTSF contributed to produce sustainable and cheaper concrete. Zhong and Zhang [3] experimented to study the workability, strength and durability of the concrete strengthened by recycled tire steel fibers (RTSF) and polypropylene fibers (PPE). It was found that the hybrid mix of RTSF and PPE combinedly improved the workability by $38.9-66 \%$. The higher amount of RTSF in hybrid reinforcement enhanced the crack resistance of concrete. Similarly, the results also indicated that the higher amount of PPE in hybrid reinforcement reduced the chlorine ingression by 4.9-6.8\%. Samindi et al. [4] presented the extensive research work on the study of the variation in the mechanical behavior of concrete reinforced with recycled steel fibers extracted from waste tires, the results of which are compared with the concrete mixes reinforced manufactured steel fibers to assess the potential of recycled steel fibers over manufactured steel fibers in view of producing sustainable concrete. Gul and Naseer [5] proposed an experimental analysis on the effect of inclusion of recycled rubber steel fibers (RRSF) on the compressive, split and flexural strength of concrete and contrasted with the results obtained from concrete mixes reinforced with manufactured steel fibers. It was observed that inclusion of recycled steel fibers reduced the compressive and split tensile behavior of concrete by $20 \%$ and $14 \%$, respectively, for $1 \%$ of RRSF by volume. Later, the strength decreased considerably with higher addition of RRSF. But the results indicated that RRSF improved the flexural behavior of concrete over manufactured steel fibers. Liew and Akbar [6] provided an exhaustive investigation report on the utilization and significance of recycled steel fibers drawn from waste tires as one of best ecofriendly and cheap strengthening element in the production of sustainable concrete. The experimental reports presented the detailed discussion on the mechanical, durability, workability, porosity, bulk density, volumetric stability and toughness of recycled steel fibred concrete. Belouadah et al. [7, 8] attempted to investigate the concrete specimens combined with glass and marble powder incorporated in varying proportions ranging from 5 to $10 \%$. It was reported from the results that addition of glass and marble powder improved the compressive performance of concrete with minimum porosity values. Belouadah et al. [7, 8] also proposed to develop a new and cheap building materials by incorporating glass and marble powder as a partial substitution of cement, and experimental investigations were carried out on cement mortar to study the physical and mechanical properties. The results obtained indicated that $10 \%$ replacement level of glass powder with cement exhibited the best performance. Rahma et al. [9] presented two sets of experiments up on concrete in which the first one is performed with partial substitutions of glass powder at the rate of $2.5 \%$ up to $15 \%$ replacement without any addition of admixture. The second one is performed with the substitutions of glass powder and plasticizer. The results obtained from second set of experiment contributed the best results. Morsli et al. [10] aimed to reduce greenhouse emissions with an approach by introducing recyclable industrial residues in place of cement in varied replacement levels. The experimental investigations confirmed the improvement in physical and mechanical properties of cement with the substitution of glass powder. Patel et al. [11] investigated on the influence of size of glass powder particles on the performance of concrete with cement replaced by glass powder in various replacement levels up to $20 \%$ of particle size $63 \mu$. Experiments were conducted to study the drying shrinkage, water absorption and strength of concrete, and results proved that $20 \%$ glass powder mix performed better than control cube. Asokan and Osmani [12] noticed that compressive strength increased drastically by $45 \%$, for $5-15 \%$ of glass powder substitution with addition of $2 \%$ super plasticizer and 
showed an increase of $11 \%$ for the same $5-15 \%$ glass powder replacement without using super plasticizer. Raharjo et al. [13] carried out his work on self-compacted concrete with the introduction of fly ash, silica fume and iron slag waste from steel mills which is replaced with fine aggregate. Tests like slump cone, L-box and V-funnel were performed to determine the flow ability of concrete. Du and Tan [14] studied a unique behavior of concrete on addition of glass powder. He noticed that resistance for alkali silica reaction and water absorption has accelerated with the substitution of cement by $60 \%$ of glass powder. Kamali and Ghahramaninezhad [15] stated that alkali silica reaction is decreased with the introduction of glass powder which is an advantage from strength point of view and also showed much resistance to chloride permeability. Islam et al. [16] showed that there is a decline in workability as glass powder is increased in the mix. Ansari and sahare experimented on $\mathrm{M} 25$ concrete incorporating glass powder and he stated that compressive strength declined by $3.56 \%$, compared to control cube but still can be considered as strength obtained is $25.10 \mathrm{~N} / \mathrm{mm}^{2}$. Harbec et al. [17] examined that compressive strength values enhanced for 7 days of curing but later decreased for 28 days of curing, with the inclusion of glass powder. Narayanan and Shanmugasundaram [18] focused on ecofriendly project with the aim to make environment green. He investigated on the concrete mix being incorporated with geopolymers, fly ash replaced with cement to investigate about thermal performance and dry density of concrete conducted under various types of curing methods. Later, it was witnessed that strength properties improved under hot air oven curing. Ramakrishnan et al. [19] performed experiments on adding ground granulated blast furnace slag in addition to glass powder and proposed that there is an increase in compressive strength at $15 \%$ glass powder and $35 \%$ GGBS replacement in place of cement. Kumar and Nagar [20] came out with a new approach with the introduction of waste glass and later described the importance of glass powder toward the enhancement of mechanical properties of concrete. Elaqra et al. [21] conducted compressive strength test for $7,14,28$ days curing at various replacements of glass powder and resulted that compressive strength is higher for $20 \%$ glass powder mixed with cement at 28 days when compared to $10 \%$ and $15 \%$ glass powder replacement. Elqra and Haloub [22] conducted a brief and long experiment where he cured the concrete cubes for 90 days, which resulted in the increase in strength when compared to conventional concrete. Ramdani et al. [23] thought of including waste glass powder as well as rubber aggregates in their work to observe the changes in the properties and figured out that at $10 \%$ substitution, compressive strength has increased. Pandurangan et al. [24] presented comprehensive efforts on the bond strength of geopolymer concrete mixed with fly ash, byproduct of thermal power plants and GGBS, industrial byproducts by conducting pull out tests, for different combination of mixes. Jain et al. [25] evaluated the durability properties of concrete with the utilization of glass powder (GP) and granite powder (GrP), replacing cement and sand in different percentages. Results indicated that a combined mix of 15\% GP and 30\% GrP significantly improved the durability properties of concrete. Gokulnath et al. [26] incorporated glass powder in self-compacting concrete (SCC) to resolve the problemsof strength and contamination issues. Experimental investigation was conducted on fresh concrete to examine workability and on hardened concrete to evaluate flexural and split tensile strength. Khan et al. [27] experimented on the impact of recycled glass powder on the properties of foam concrete. It was observed that $20 \%$ glass powder mix replaced with cement increased the compressive strength of concrete. He et al. [28] discussed the use and impact of glass powder as a partial substitute of cement to study the creep behavior of concrete. Introduction of glass powder less than $20 \%$ effectively improved the creep and compressive strength of concrete at later ages. Hama et al. [29] focussed to study the flexural behavior of structurally reinforced concrete beams with the incorporation of glass powder. It is seen that beams modified with glass powder exhibited better flexural performance than ordinary concrete beams. Rehman et al. [30] investigated the properties of self-compacting concrete by substituting cement by glass powder and sand by granular steel slag. The increasing replacement levels of granular steel slag with constant mix of glass powder improved the strength and modulus of elasticity. Bostanci [31] presented his work on the efficient use of marble dust and glass powder in place of cement and sand, respectively, and resulted that compressive strength declines by $10-19 \%$ for mixes added with recycled glass and marble dust, but permeability and thermal conductivity performance enhanced. Yasouj and Ghaderi [32] conducted experiments to develop the optimum mix upon utilization of waste glass powder (WGP), basalt fiber (BF) and carbon nanotube (CNT) in concrete. It is observed that $20 \%$ GP mix incorporated with $0.2 \% \mathrm{BF}$ and $0.1 \%$ CNT exhibited higher mechanical properties. Wang et al. [33] aimed at establishing a correlation between compressive strength and ultra-sonic pulse velocity (UPV) of concrete mixed with waste LCD glass in different levels. It was concluded that UPV values increase and compressive strength decreases with the increase in glass powder content. Aliabdo et al. [34 proposed the effect of waste glass powder on concrete properties by replacing cement with glass powder up to $25 \%$ and presented that $15 \%$ glass powder mix enhanced compressive strength by $16 \%$ and showed better performance compared to ordinary concrete. In this 
Table 1 Physical properties of 53 grade OP cement

\begin{tabular}{ll}
\hline Compressive strength in $\mathrm{N} / \mathrm{mm}^{2}$ & 53 \\
Fineness in $\mathrm{m}^{2} / \mathrm{kg}$ & 225 \\
Initial setting time (minimum) & $33 \mathrm{~min}$ \\
Final setting time (maximum) & $600 \mathrm{~min}$ \\
Soundness (expansion) in $\mathrm{mm}$ & 10 \\
Autoclave test for MgO percent (maximum) & 0.8 \\
\hline
\end{tabular}

Table 2 Chemical properties of 53 OP grade cement

\begin{tabular}{ll}
\hline Loss on ignition (\%) & 4 \\
Insoluble residue (\%) maximum & 2 \\
Magnesia MgO (\%) maximum & 6 \\
$\mathrm{SO}_{3}(\%)$ maximum & 2.5 \\
Lime saturation factor & $0.8-1.25$
\end{tabular}

present work, a detailed study is done, exclusively by introducing WGP and RSF to come out with objectives as follows:

a. To study the effect of glass powder and recycled steel fibers on the workability of concrete.

b. To examine the variations in the compressive, flexural and split tensile strength upon utilization of glass powder and recycled steel fibers in concrete.

\section{Experimental investigation and methodology}

\subsection{Cement}

Cement is a good binding material which constitutes the major component in the manufacturing of concrete. One of the fundamental properties of cement is because of its adhesive and cohesive nature; it binds all the other raw materials to form a good bond. Ordinary Portland cement of grade 53 is used whose physical and chemical properties are listed in Tables 1 and 2.

\subsection{Fine aggregate}

As per Indian Standard IS:383 classification, fine aggregate is categorized into four zones. Sieve analysis report shown in Table 3 confirms that sand utilized belongs to Zone-II whose gradation curve and physical properties are shown in Fig. 1 and Table 4, respectively.

\subsection{Coarse aggregate}

Coarse aggregates which retain on 4.75-mm IS sieve are another important raw material which helps in increasing the volume and hardness of concrete. As per IS: 383 , the coarse aggregate used is are single-sized crush angular coarse aggregates of nominal size $20 \mathrm{~mm}$ confirmed from the sieve analysis report shown in Table 5 . The gradation curve and its physical properties are presented in Fig. 2 and Table 6.

\subsection{Water}

Ordinary tap water is not preferred generally for mixing as it contains various acids, alkalis, organic impurities due to hardness of water which degrades the quality of concrete. Generally, it is better to use potable water. It acts as a lubricant which later responsible for chemical reaction between cements and water. Normal tap water is used in the present work (Table 7).

\subsection{Recycled steel fibers}

Recycled steel fibers of aspect ratio 50 with $30 \mathrm{~mm}$ length and $0.5 \mathrm{~mm}$ diameter were extracted from waste tires and utilized as a reinforcing element in concrete mix. Waste
Table 3 Sieve analysis for fine aggregate

\begin{tabular}{|c|c|c|c|c|c|c|c|}
\hline \multirow[t]{2}{*}{ Sieve size (mm) } & \multicolumn{4}{|c|}{ Weight $(\mathrm{g})$ retained on each sieve } & \multirow{2}{*}{$\begin{array}{l}\% \text { Weight } \\
\text { retained }\end{array}$} & \multirow{2}{*}{$\begin{array}{l}\text { Cumulative } \% \\
\text { weight retained }\end{array}$} & \multirow[t]{2}{*}{$\%$ Finer } \\
\hline & 1 & II & III & Avg & & & \\
\hline 10 & 0 & 0 & 5 & 1.67 & 0.17 & 0.17 & 99.8 \\
\hline 4.75 & 11 & 13 & 16 & 13.33 & 1.33 & 1.50 & 98.5 \\
\hline 2.36 & 37 & 29 & 21 & 29.00 & 2.90 & 4.40 & 95.6 \\
\hline 1.18 & 315 & 323 & 331 & 323.00 & 32.30 & 36.70 & 63.3 \\
\hline 0.6 & 211 & 187 & 222 & 206.67 & 20.67 & 57.37 & 42.6 \\
\hline 0.3 & 271 & 289 & 265 & 275.00 & 27.50 & 84.87 & 15.1 \\
\hline 0.15 & 111 & 104 & 111 & 108.67 & 10.87 & 95.73 & 4.3 \\
\hline 0.075 & 19 & 24 & 16 & 19.67 & 1.97 & 97.70 & 2.3 \\
\hline Pan & 25 & 29 & 14 & 22.67 & 2.27 & 100.00 & 0.0 \\
\hline
\end{tabular}


Fig. 1 Gradation curve for fine aggregate

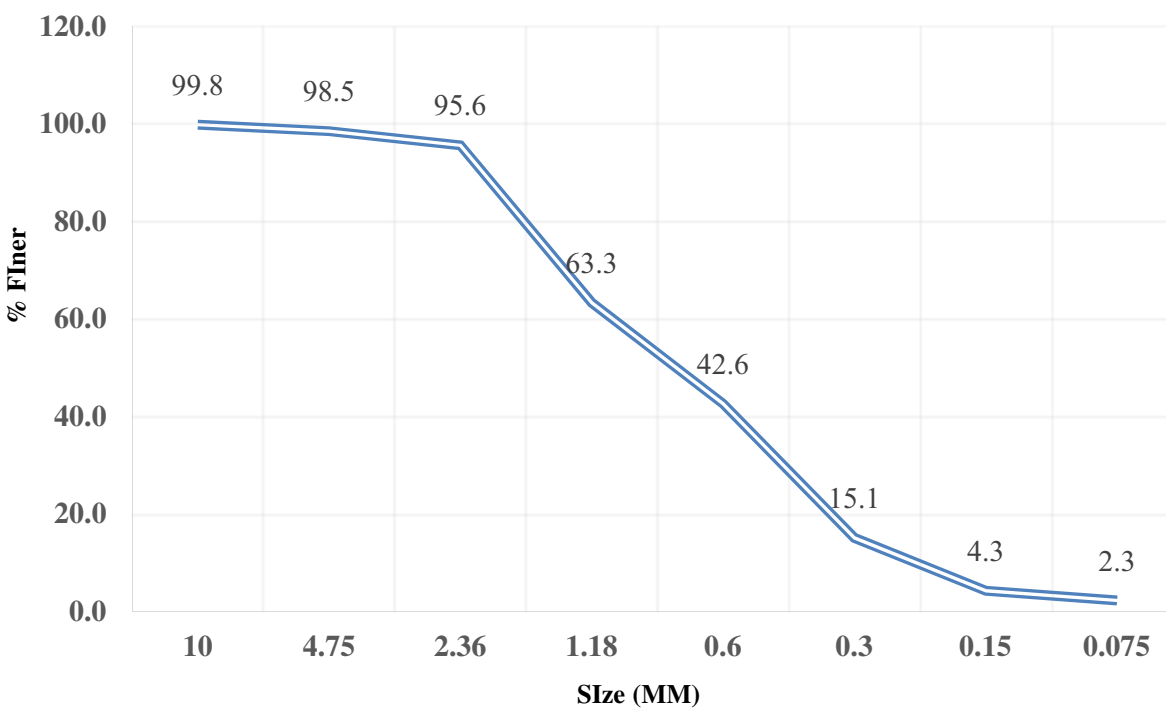

Table 4 Physical properties of Zone-II fine aggregate

\begin{tabular}{lc}
\hline Fineness modulus & 2.84 \\
Uniformity coefficient & 3.41 \\
Specific gravity & 2.67 \\
Bulking & $33.3 \%$ \\
Water absorption & $0.86 \%$ \\
\hline
\end{tabular}

rubber tires and extracted steel fibers from tires are shown in Figs. 3 and 4, respectively.

\subsection{Admixture}

A chemical Superplasticizer "Conplast SP 430" is used for the preparation of concrete specimens. It is made of sulfonated naphthalene polymer, specified as per IS: 9103-979.

\subsection{Waste glass powder}

Glass is a substance which basically consists of silica and hence can be replaced with fine aggregate. Glass is manufactured by subjecting few raw materials such as quartz, feldspar, china clay dolomite and calcium carbonate to high temperature. After melting, the molten mixture is allowed to cool where it solidifies to form a crystalline transparent substance called glass. Glass is having a wide range of applications in our daily lives as sheet glass, glass bottles, glassware, etc. Glass bottles from junkshops are used in this study. Bottles chosen should be clean and must be of same property and are first manually crushed and then later carried to crushing mill where glass pieces were further crushed to form a uniform fine powder. The crushed powder is then processed to have a uniform size of less than $2.0 \mathrm{~mm}$ but greater than $0.075 \mathrm{~mm}$ in accordance to ASTM standards through sieving as shown in Figs. 5 and 6 clearly.

\subsection{Sieve analysis and gradation curve for waste glass powder}

As the waste glass powder is replaced with fine aggregate, powdered waste glass powder obtained after grinding is passed through the same sieve sizes as considered for fine aggregate and the gradation curve is shown in Fig. 7, drawn as per the sieve analysis report presented in Table 8 .
Table 5 Sieve analysis for coarse aggregate

\begin{tabular}{|c|c|c|c|c|c|c|c|}
\hline \multirow[t]{2}{*}{ Sieve size (mm) } & \multicolumn{4}{|c|}{ Weight $(\mathrm{g})$ retained on each sieve } & \multirow{2}{*}{$\begin{array}{l}\% \text { Weight } \\
\text { retained }\end{array}$} & \multirow{2}{*}{$\begin{array}{l}\text { Cumulative } \% \\
\text { weight retained }\end{array}$} & \multirow[t]{2}{*}{$\%$ Finer } \\
\hline & 1 & II & III & Avg & & & \\
\hline 20 & 0 & 0 & 0 & 0.0 & 0.0 & 0 & 100 \\
\hline 16 & 53 & 47 & 45 & 48.3 & 4.8 & 4.8 & 95.2 \\
\hline 12.5 & 535 & 453 & 491 & 493.0 & 49.3 & 54.1 & 45.9 \\
\hline 10 & 321 & 410 & 397 & 376.0 & 37.6 & 91.7 & 8.3 \\
\hline 4.75 & 84 & 81 & 58 & 74.3 & 7.4 & 99.1 & 0.9 \\
\hline Pan & 5 & 11 & 9 & 8.3 & 0.8 & 100.0 & 0 \\
\hline
\end{tabular}


Fig. 2 Gradation curve for coarse aggregate

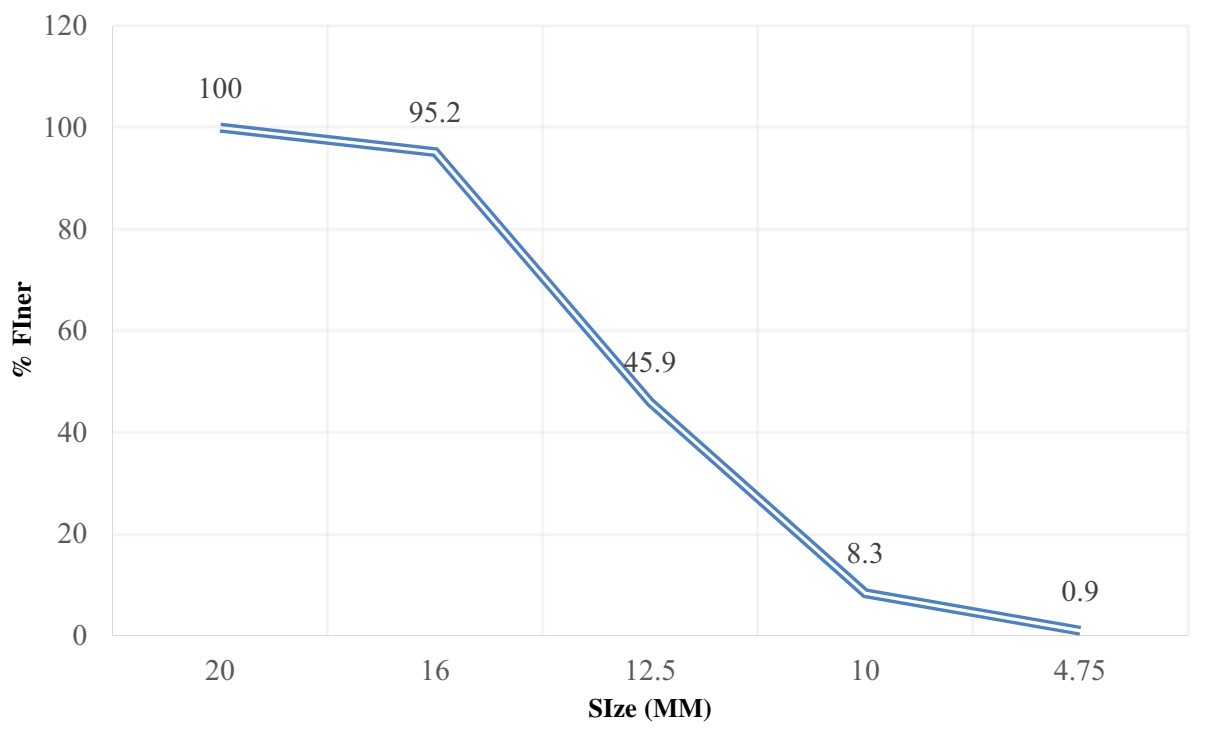

Table 6 Physical properties of coarse aggregates

\begin{tabular}{ll}
\hline Fineness modulus & 7.56 \\
Specific gravity & 2.74 \\
Aggregate crushing value & $26 \%$ \\
Water absorption & $1.25 \%$ \\
\hline
\end{tabular}

Table 7 Chemical and physical composition of waste glass powder

\begin{tabular}{llll}
\hline Composition & Value (\%) & Composition & Value \\
\hline $\mathrm{SiO}_{2}$ & 65 & Specific gravity & 2.7 \\
$\mathrm{Al}_{2} \mathrm{O}_{3}$ & 3 & Density & $2555 \mathrm{~kg} / \mathrm{m}^{3}$ \\
$\mathrm{CaO}$ & 18.5 & Specific surface area & $3230 \mathrm{~m}^{2} / \mathrm{kg}$ \\
$\mathrm{Na}_{2} \mathrm{O}$ & 13 & & \\
$\mathrm{~K}_{2} \mathrm{O}$ & 1.5 & & \\
\hline
\end{tabular}

\subsection{Mix design of M30 grade concrete}

- Type of cement: OPC 53 grade

- Maximum size of coarse aggregate: $20 \mathrm{~mm}$

- Exposure condition: moderate

- Coarse aggregate shape: crushed angular shape

- Fine aggregate: Zone-II

- Design mix target slump: $75 \mathrm{~mm}$

- Specific gravity of cement: 3.15

- Water absorption of C.A: $0.86 \%$

- Water absorption of F.A: $1.25 \%$

\subsubsection{Mean target strength of concrete}

$$
\begin{aligned}
\mathrm{fm}= & \mathrm{fck}+1.65 \mathrm{~S}=30+1.65 \\
& \times 5(\mathrm{~S}=5 \text { as per IS } 456: 2000)=38 \mathrm{~N} / \mathrm{mm}^{2}
\end{aligned}
$$

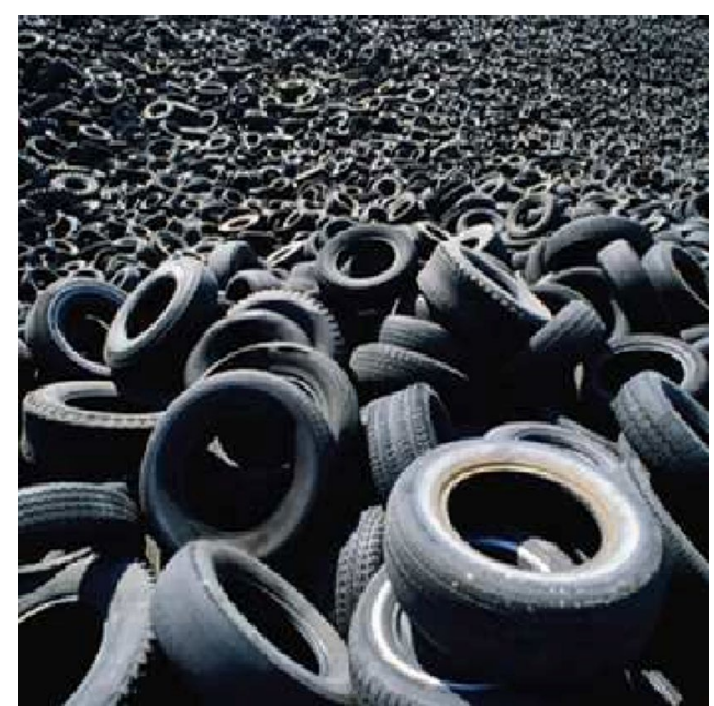

Fig. 3 Waste rubber tires

where $\mathrm{fm}$ is the target mean strength, $\mathrm{fck}$ is the characteristic compressive strength of cube and $S$ is the standard deviation.

\subsubsection{Determination of $\mathrm{W} / \mathrm{C}$ ratio}

- As per IS 456:2000, since moderate exposure

- Maximum $W / C$ ratio $=0.5$

- Adopt $\mathrm{W} / \mathrm{C}$ ratio as per experience $=0.5-0.05=0.45$ 


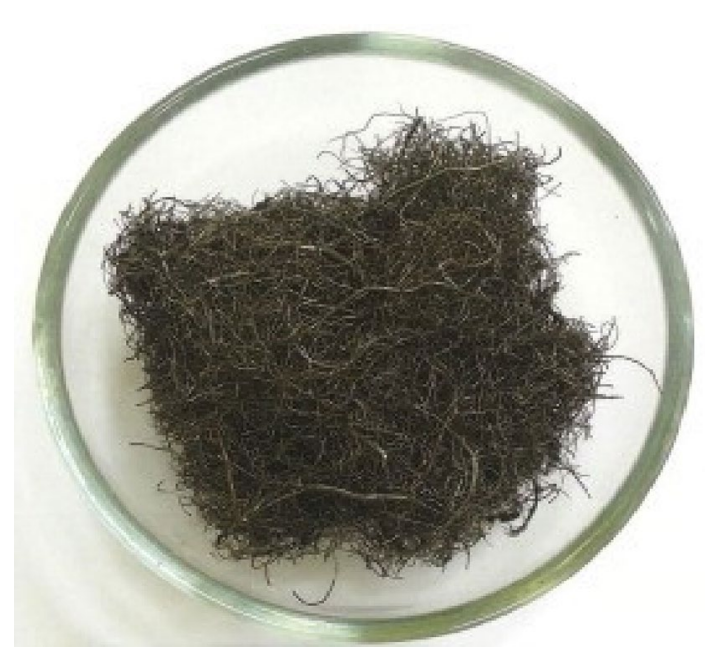

Fig. 4 Extracted steel fibers

\subsubsection{Calculation of water content (W.C)}

Maximum W.C to be adopted for $20 \mathrm{~mm}$ coarse aggregate as per IS 10260:2009 is $186 \mathrm{~L}$.

Our target of slump is $75 \mathrm{~mm}$. As per IS 10262, it is required to add $3 \%$ more water content for every $25 \mathrm{~mm}$ slump. The minimum water content, i.e., $186 \mathrm{~L}$, obtained here is sufficient to attain $50 \mathrm{~mm}$ slump. Therefore, to attain $75 \mathrm{~mm}$ target slump, we need to add $3 \%$ more water content.

- Estimated W.C for $75 \mathrm{~mm}$ slump $=186+(3 \%$ of 186) $=191.58$ litres

- As admixture is used, W.C is decreased by $15 \%$

- Actual W.C required $=191.58-(15 \%$ of 191.58) $=162.84$ litres

\subsection{Cement content}

- $\mathrm{W} / \mathrm{C}$ ratio $=0.45$

- W.C used $=162.84$ litres
- Cement content $=162.84 / 0.45=361.86 \mathrm{~kg} / \mathrm{m}^{3}$

\subsection{Calculation of volume of coarse and fine aggregate}

- Volume of coarse aggregate of size $20 \mathrm{~mm}$ and sand of Zone-II to be adopted, for $\mathrm{W} / \mathrm{C}$ ratio $0.5=0.64$

- As the W/C ratio is reduced by 0.05 , volume of coarse aggregate is increased at a rate 0.01 for every 0.05 decrease in water content

- Corrected volume of coarse aggregate $=0.64+0.01=0.65$

- As per IS 10262:2009, volume of coarse aggregate is decreased by $10 \%$ because of angular shape. Therefore, volume of coarse aggregate $=0.65-(0.1 \times 0.65)=0.585$

- Fine aggregate volume $=1-0.585=0.415$

\subsubsection{Design mix calculation for $1 \mathrm{~m}^{3}$ concrete}

a. Vol. of cement

$$
=\frac{\text { mass of cement }}{\text { specific gravity of cement } \times 1000}=\frac{361.86}{3.15 \times 1000}=0.114 \mathrm{~m}^{3}
$$

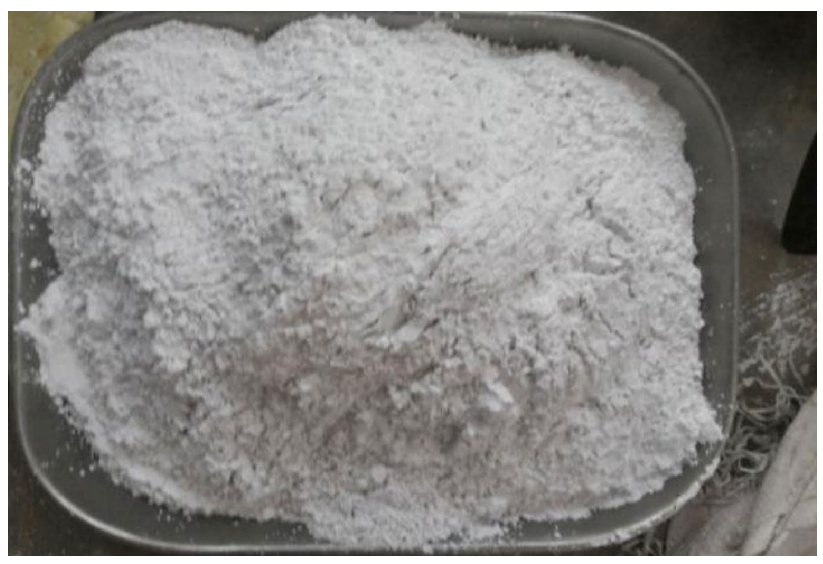

Fig. 6 Fine recycled glass powder

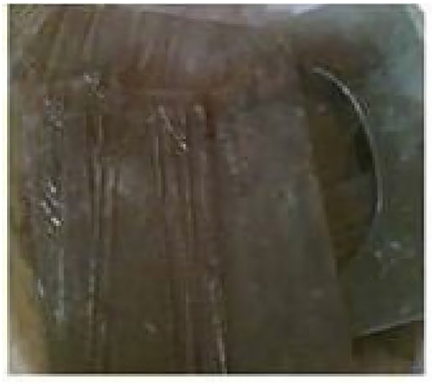

Sheet Glass

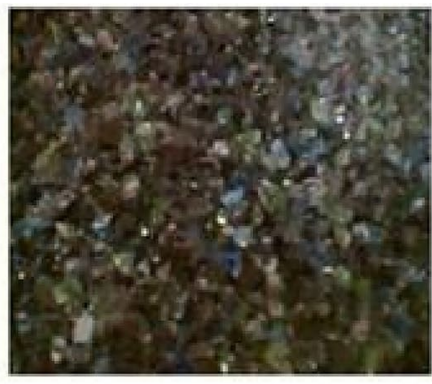

Crushed Sheet Glass

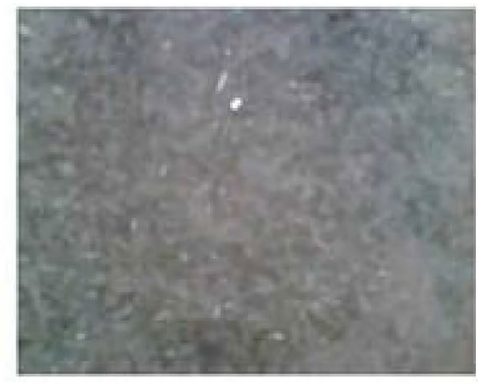

Sheet Glass Powder

Fig. 5 Various forms of glass powder 
Fig. 7 Gradation curve for waste glass powder
Table 8 Sieve analysis for waste glass powder

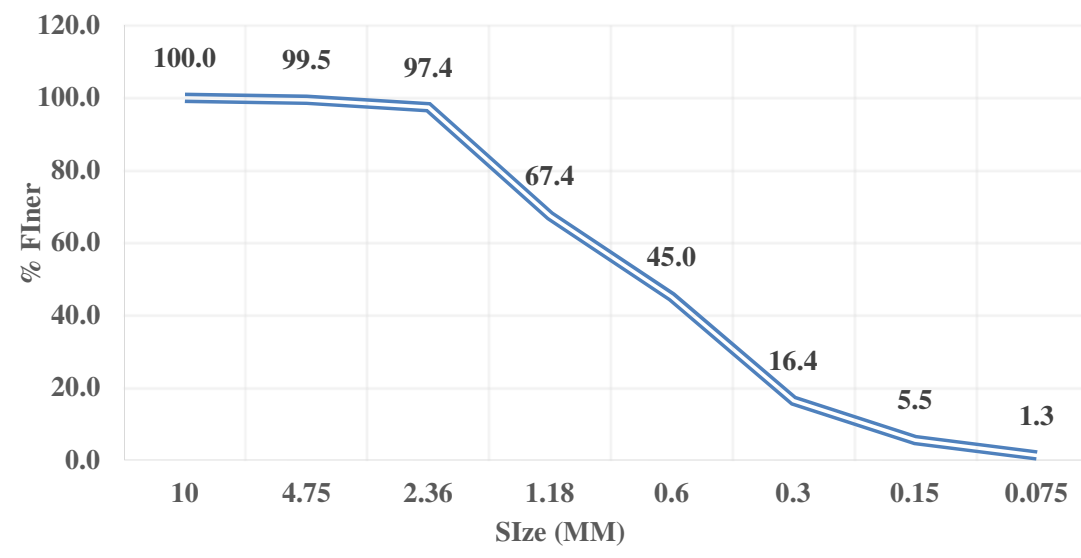

\begin{tabular}{|c|c|c|c|c|c|c|c|}
\hline \multirow[t]{2}{*}{ Sieve size $(\mathrm{mm})$} & \multicolumn{4}{|c|}{ Weight (g) retained on each sieve } & \multirow{2}{*}{$\begin{array}{l}\% \text { Weight } \\
\text { retained }\end{array}$} & \multirow{2}{*}{$\begin{array}{l}\text { Cumulative \% } \\
\text { weight retained }\end{array}$} & \multirow[t]{2}{*}{$\%$ Finer } \\
\hline & 1 & II & III & Avg & & & \\
\hline 10 & 0 & 0 & 0 & 0.00 & 0.00 & 0.0 & 100.0 \\
\hline 4.75 & 6 & 5 & 5 & 5.33 & 0.53 & 0.5 & 99.5 \\
\hline 2.36 & 21 & 18 & 23 & 20.67 & 2.07 & 2.6 & 97.4 \\
\hline 1.18 & 298 & 296 & 306 & 300.00 & 30.00 & 32.6 & 67.4 \\
\hline 0.6 & 226 & 229 & 216 & 223.67 & 22.37 & 55.0 & 45.0 \\
\hline 0.3 & 281 & 293 & 286 & 286.67 & 28.67 & 83.6 & 16.4 \\
\hline 0.15 & 111 & 104 & 111 & 108.67 & 10.87 & 94.5 & 5.5 \\
\hline 0.075 & 43 & 36 & 48 & 42.33 & 4.23 & 98.7 & 1.3 \\
\hline Pan & 13 & 11 & 12 & 12.00 & 1.20 & 100.0 & 0.0 \\
\hline
\end{tabular}
b. Vol.ofwater $=\frac{\text { mass of water }}{\text { specific gravity of water } \times 1000}=\frac{162.84}{1 \times 1000}=0.162 \mathrm{~m}$

c. Vol. of admixture (taking $2 \%$ by mass of cementitious material with specific gravity 1.12)

$=\frac{\text { mass of admixture }}{\text { specific gravity of admixture } \times 1000}=\frac{7.22}{1.2 \times 1000}=0.006 \mathrm{~m}^{3}$

d. Vol. of entrapped air $=2 \%$ for $20 \mathrm{~mm}$ coarse aggregate $=0.02 \mathrm{~m}^{3}$

e. Vol. of all aggregate (coarse + fine $)=1-(0.114+0.162+$ $0.006+0.02)=0.698 \mathrm{~m}^{3}$

f. Mass of coarse aggregate $=$ vol. of all aggregate $\times$ vol. of coarse aggregate $\times$ specific gravity $\times 1000$

$=0.698 \times 0.585 \times 2.74 \times 1000=1118.82 \mathrm{~kg}$

g. Mass of fine aggregate $=$ vol. of all aggregate $\times$ vol. of sand $\times$ specific gravity $\times 1000$

$=0.698 \times 0.415 \times 2.67 \times 1000=773.41 \mathrm{~kg}$

\subsubsection{Mix proportion of M30 Grade concrete per $\mathrm{m}^{3}$ volume}

Quantity of cement used $=361.86 \mathrm{~kg}$
Quantity of fine aggregate $=773.41 \mathrm{~kg}$

Quantity of coarse aggregate $=1118.82 \mathrm{~kg}$

\subsection{Casting of specimens}

In the present thesis, numerous specimens were casted to analyze the test results such that 2 cubes $(150 \times 150 \times 150 \mathrm{~mm})$ for compressive strength, 2 beams $(100 \times 100 \times 500 \mathrm{~mm})$ for flexural strength and 2 cylinders (300 $\mathrm{mm}$ diameter and $600 \mathrm{~mm}$ height) for split tensile strength for every proportion of glass powder replacement with and without addition of steel fibers as mentioned briefly in Table 9.

\subsubsection{Number of specimens casted}

Number of cubes $=96$, Number of beams $=96$, Number of cylinders $=96$, Total number of specimens $=288$.

\subsection{Testing procedure}

\subsubsection{Testing of fresh concrete}

Workability is one such property which enables the concrete the ease in mixing, placing and compacting. 
Table 9 Concrete mixes

\begin{tabular}{|c|c|c|c|c|c|c|c|c|c|c|c|}
\hline Cube & Beam & Cylinder & Sand (\%) & $\begin{array}{l}\text { Glass } \\
\text { powder } \\
(\%)\end{array}$ & Steel fiber (\%) & Cube & Beam & Cylinder & Sand (\%) & $\begin{array}{l}\text { Glass } \\
\text { powder } \\
(\%)\end{array}$ & Steel fiber (\%) \\
\hline $\mathrm{C} 1,1$ & $\mathrm{~B} 1,1$ & $\mathrm{~A} 1,1$ & 100 & 0 & 0 & $\mathrm{C} 13,1$ & $\mathrm{~B} 13,1$ & $\mathrm{~A} 13,1$ & 100 & 0 & 1 \\
\hline $\mathrm{C} 1,2$ & $\mathrm{~B} 1,2$ & $A 1,2$ & 100 & 0 & 0 & $\mathrm{C} 13,2$ & $\mathrm{~B} 13,2$ & $\mathrm{~A} 13,2$ & 100 & 0 & 1 \\
\hline$C 2,1$ & $\mathrm{~B} 2,1$ & $\mathrm{~A} 2,1$ & 97 & 3 & 0 & $\mathrm{C} 14,1$ & $\mathrm{~B} 14,1$ & $\mathrm{~A} 14,1$ & 97 & 3 & 1 \\
\hline$C 2,2$ & $\mathrm{~B} 2,2$ & $A 2,2$ & 97 & 3 & 0 & $\mathrm{C} 14,2$ & $\mathrm{~B} 14,2$ & A 14,2 & 97 & 3 & 1 \\
\hline$C 3,1$ & $\mathrm{~B} 3,1$ & $A 3,1$ & 94 & 6 & 0 & $\mathrm{C} 15,1$ & $\mathrm{~B} 15,1$ & $\mathrm{~A} 15,1$ & 94 & 6 & 1 \\
\hline$C 3,2$ & $\mathrm{~B} 3,2$ & $A 3,2$ & 94 & 6 & 0 & $\mathrm{C} 15,2$ & B15,2 & A15,2 & 94 & 6 & 1 \\
\hline$C 4,1$ & $\mathrm{~B} 4,1$ & $\mathrm{~A} 4,1$ & 91 & 9 & 0 & $\mathrm{C} 16,1$ & $\mathrm{~B} 16,1$ & $\mathrm{~A} 16,1$ & 91 & 9 & 1 \\
\hline$C 4,2$ & $B 4,2$ & $\mathrm{~A} 4,2$ & 91 & 9 & 0 & $C 16,2$ & B16,2 & A16,2 & 91 & 9 & 1 \\
\hline$C 5,1$ & $\mathrm{~B} 5,1$ & $A 5,1$ & 88 & 12 & 0 & $\mathrm{C} 17,1$ & $\mathrm{~B} 17,1$ & $\mathrm{~A} 17,1$ & 88 & 12 & 1 \\
\hline$C 5,2$ & $\mathrm{~B} 5,2$ & $A 5,2$ & 88 & 12 & 0 & $\mathrm{C} 17,2$ & B17,2 & $\mathrm{A} 17,2$ & 88 & 12 & 1 \\
\hline$C 6,1$ & $\mathrm{~B} 6,1$ & $A 6,1$ & 85 & 15 & 0 & $\mathrm{C} 18,1$ & B18,1 & $\mathrm{A} 18,1$ & 85 & 15 & 1 \\
\hline C6,2 & B6,2 & $A 6,2$ & 85 & 15 & 0 & C18,2 & B18,2 & A 18,2 & 85 & 15 & 1 \\
\hline$C 7,1$ & $B 7,1$ & $A 7,1$ & 100 & 0 & 0.5 & $\mathrm{C} 19,1$ & B19,1 & $\mathrm{A} 19,1$ & 100 & 0 & 1.5 \\
\hline$C 7,2$ & $B 7,2$ & $A 7,2$ & 100 & 0 & 0.5 & $\mathrm{C} 19,2$ & B19,2 & A19,2 & 100 & 0 & 1.5 \\
\hline$C 8,1$ & $\mathrm{~B} 8,1$ & $A 8,1$ & 97 & 3 & 0.5 & $C 20,1$ & B20,1 & $A 20,1$ & 97 & 3 & 1.5 \\
\hline$C 8,2$ & $B 8,2$ & $A 8,2$ & 97 & 3 & 0.5 & $C 20,2$ & B20,2 & $A 20,2$ & 97 & 3 & 1.5 \\
\hline$C 9,1$ & B9,1 & $A 9,1$ & 94 & 6 & 0.5 & $C 21,1$ & B21,1 & $\mathrm{A} 21,1$ & 94 & 6 & 1.5 \\
\hline$C 9,2$ & $B 9,2$ & $A 9,2$ & 94 & 6 & 0.5 & $C 21,2$ & B21,2 & $A 21,2$ & 94 & 6 & 1.5 \\
\hline $\mathrm{C} 10,1$ & B10,1 & $\mathrm{A} 10,1$ & 91 & 9 & 0.5 & $C 22,1$ & B22, 1 & $\mathrm{~A} 22,1$ & 91 & 9 & 1.5 \\
\hline $\mathrm{C} 10,2$ & B10,2 & $\mathrm{A} 10,2$ & 91 & 9 & 0.5 & $C 22,2$ & B22,2 & $\mathrm{A} 22,2$ & 91 & 9 & 1.5 \\
\hline $\mathrm{C} 11,1$ & B11,1 & $\mathrm{A} 11,1$ & 88 & 12 & 0.5 & $C 23,1$ & $\mathrm{~B} 23,1$ & $A 23,1$ & 88 & 12 & 1.5 \\
\hline $\mathrm{C} 11,2$ & B11,2 & A11,2 & 88 & 12 & 0.5 & $C 23,2$ & B23,2 & $A 23,2$ & 88 & 12 & 1.5 \\
\hline$C 12,1$ & B12,1 & $\mathrm{A} 12,1$ & 85 & 15 & 0.5 & $C 24,1$ & B24, 1 & $\mathrm{~A} 24,1$ & 85 & 15 & 1.5 \\
\hline $\mathrm{C} 12,2$ & $\mathrm{~B} 12,2$ & $\mathrm{~A} 12,2$ & 85 & 15 & 0.5 & $C 24,2$ & B24,2 & $\mathrm{A} 24,2$ & 85 & 15 & 1.5 \\
\hline
\end{tabular}

where $\mathrm{C}$ for cubes, $\mathrm{B}$ for beams, $\mathrm{A}$ for cylinders

Generally, workability is determined when the concrete is under fresh state and several tests are performed to determine the workability. Here, slump test is performed in accordance with TS 2871 standard to assess workability. Every concrete mix, with and without replacement percentage of glass powder and steel fibers, was tested for workability by slump test, for which slump value was around $75-85 \mathrm{~mm}$. However, it is examined that addition of glass powder with the partial substitution of fine aggregates resulted to an increase in workability which is an additive factor for having good concrete mix which is presented in Table 10.

\subsubsection{Testing of hardened concrete}

Every concrete mix after hardening was tested for compressive, flexural and split tensile strength in accordance with TS3114 ISO 4012 standard for $7 \mathrm{~d}$ and $28 \mathrm{~d}$ curing, and the obtained results were discussed and analyzed.

Alkali silicate reaction is one of the adverse reactions which degrade the strength of concrete. It is the reaction
Table 10 Slump values for various replacements of glass powder

\begin{tabular}{lll}
\hline S. no & Glass powder (\%) replacement & $\begin{array}{l}\text { Slump } \\
\text { value } \\
(\mathrm{mm})\end{array}$ \\
\hline 1 & 0 & 74 \\
2 & 3 & 77 \\
3 & 6 & 78 \\
4 & 9 & 81 \\
5 & 12 & 82 \\
6 & 15 & 85 \\
\hline
\end{tabular}

that occurs between the alkali solution of cement paste and silica present in aggregates, which leads to the formation of silica gel that expands and results in the formation of cracks. As glass is a rich source of silicon dioxide, it may have the potential to aggravate the alkali silica reaction. However, it has been seen from the previous studies about the impact of glass powder on alkali silica reaction that crushed glass used as a partial substitution of cement or 
sand enhanced the alkali silica expansion, but instead, finely ground glass powder helps in preventing the alkali silica reaction expansion. Here, the addition of glass powder of size ranging between 0.075 and $2 \mathrm{~mm}$, substituted by fine aggregate does not cause any significant changes in Alkali silica reaction.

\section{Results and discussions}

\subsection{Compressive strength results}

Cubes prepared by the combinations of waste glass powder and recycled steel fibers in the mix are experimented to obtain the compressive strength results for 7 and 28 days curing.

\subsubsection{For 7-day curing period}

The following tables shows the compressive strength results of all concrete mixes composed of different percentages of waste glass powder (WGP) and recycled steel fibers (RSF) after 7 days curing (Table 11).

\subsubsection{For 28-day curing period}

The following tables shows the compressive strength results of all concrete mixes composed of different percentages of waste glass powder (WGP) and recycled steel fibers (RSF) after 28 days curing.

\subsubsection{Graphs depicting for 7 days curing}

The following graphs show the compressive strength results of all concrete mixes composed of different percentages of waste glass powder (WGP) and recycled steel fibers (RSF) after 7 days curing (Table 12).

\subsection{Discussions}

Initially compressive strength tests were performed for every concrete mix with varying replacement levels of waste glass powder $0 \%, 3 \%, 6 \%, 9 \%, 12 \%$ and $15 \%$, reinforced with $0 \%, 0.5 \%, 1 \%, 1.5 \%$ addition of recycled steel fibers, and the tests results were compared and analyzed with control specimen after 7-day curing period. Figure 8 shows that compressive strength significantly improved with the utilization of WGP especially at $9 \%$ replacement of WGP for all percentage inclusion of RSF. The maximum compressive strength of $25.45 \mathrm{~N} / \mathrm{mm}^{2}$ is seen for $9 \%$ mix of WGP with $1 \%$ inclusion of RSF that showed a rise of $13.24 \%$ over control specimen. The least compressive strength of $22.575 \mathrm{~N} / \mathrm{mm}^{2}$ is obtained for $15 \%$ replacement level of WGP with $1.5 \%$ inclusion of RSF that showed a slight increment of $0.44 \%$ over control specimen as shown in the above graph which clearly indicates that the inclusion of RSF higher than $1 \%$ and utilization of waste glass powder higher than $9 \%$ substitution and reduces the compressive strength of compressive strength.

Table 11 Compressive strength results for various replacements of WGP with $0 \%, 0.5 \%, 1 \%, 1.5 \%$ additions of RSF

\begin{tabular}{|c|c|c|c|c|c|c|c|c|c|}
\hline \multirow[t]{2}{*}{ Sl.no } & \multirow[t]{2}{*}{$\%$ WGP } & \multicolumn{3}{|l|}{$\%$ RSF 0} & \multirow{2}{*}{$\begin{array}{l}\% \text { Increase over } \\
\text { control speci- } \\
\text { men }\end{array}$} & \multicolumn{3}{|l|}{ \% RSF 0.5} & \multirow{2}{*}{$\begin{array}{l}\% \text { Increase over } \\
\text { control speci- } \\
\text { men }\end{array}$} \\
\hline & & $\mathrm{S}-1\left(\mathrm{~N} / \mathrm{mm}^{2}\right)$ & $\mathrm{S}-2\left(\mathrm{~N} / \mathrm{mm}^{2}\right)$ & Mean $\left(\mathrm{N} / \mathrm{mm}^{2}\right)$ & & $\mathrm{S}-1\left(\mathrm{~N} / \mathrm{mm}^{2}\right)$ & $\mathrm{S}-2\left(\mathrm{~N} / \mathrm{mm}^{2}\right)$ & Mean $\left(\mathrm{N} / \mathrm{mm}^{2}\right)$ & \\
\hline 1 & 0 & 21.36 & 23.59 & 22.475 & 0.00 & 22.85 & 24.21 & 23.53 & 4.69 \\
\hline 2 & 3 & 21.96 & 23.97 & 22.965 & 2.18 & 21.94 & 23.56 & 22.75 & 1.22 \\
\hline 3 & 6 & 22.97 & 23.41 & 23.19 & 3.18 & 22.82 & 24.63 & 23.725 & 5.56 \\
\hline 4 & 9 & 22.69 & 24.89 & 23.79 & 5.85 & 24.87 & 25.11 & 24.99 & 11.19 \\
\hline 5 & 12 & 23.36 & 23.53 & 22.945 & 2.09 & 22.54 & 24.71 & 23.625 & 5.12 \\
\hline 6 & 15 & 21.89 & 23.69 & 22.79 & 1.40 & 23.43 & 24.11 & 23.77 & 5.76 \\
\hline \multirow[t]{2}{*}{ Sl.no } & \multirow[t]{2}{*}{$\%$ WGP } & \multicolumn{3}{|l|}{ \% RSF 1} & $\%$ Increase over & \multicolumn{3}{|l|}{ \% RSF 1.5} & \multirow{2}{*}{$\begin{array}{l}\% \text { Increase ove } \\
\text { control speci- } \\
\text { men }\end{array}$} \\
\hline & & $\mathrm{S}-1\left(\mathrm{~N} / \mathrm{mm}^{2}\right)$ & $\mathrm{S}-2\left(\mathrm{~N} / \mathrm{mm}^{2}\right)$ & Mean $\left(\mathrm{N} / \mathrm{mm}^{2}\right)$ & men & $\mathrm{S}-1\left(\mathrm{~N} / \mathrm{mm}^{2}\right)$ & $\mathrm{S}-2\left(\mathrm{~N} / \mathrm{mm}^{2}\right)$ & Mean $\left(\mathrm{N} / \mathrm{mm}^{2}\right)$ & \\
\hline 1 & 0 & 23.41 & 24.22 & 23.815 & 5.96 & 21.75 & 23.56 & 22.655 & 0.80 \\
\hline 2 & 3 & 22.99 & 24.93 & 23.96 & 6.61 & 21.86 & 23.41 & 22.745 & 1.20 \\
\hline 3 & 6 & 23.18 & 25.26 & 24.22 & 7.76 & 22.31 & 25.12 & 23.715 & 5.52 \\
\hline 4 & 9 & 24.51 & 26.39 & 25.45 & 13.24 & 23.41 & 26.34 & 24.875 & 10.68 \\
\hline 5 & 12 & 23.31 & 25.32 & 24.315 & 8.19 & 22.12 & 24.13 & 23.125 & 2.89 \\
\hline 6 & 15 & 23.89 & 23.93 & 23.91 & 6.38 & 22.96 & 22.19 & 22.575 & 0.44 \\
\hline
\end{tabular}


Table 12 Compressive strength results for various replacements of WGP with $0 \%, 0.5 \%, 1 \%, 1.5 \%$ additions of RSF

\begin{tabular}{|c|c|c|c|c|c|c|c|c|c|}
\hline \multirow[t]{2}{*}{ Sl.no } & \multirow[t]{2}{*}{$\%$ WGP } & \multicolumn{3}{|l|}{$\%$ RSF 0} & \multirow{2}{*}{$\begin{array}{l}\% \text { Increase over } \\
\text { control speci- } \\
\text { men }\end{array}$} & \multicolumn{3}{|l|}{ \% RSF 0.5} & \multirow{2}{*}{$\begin{array}{l}\text { \% Increase over } \\
\text { control speci- } \\
\text { men }\end{array}$} \\
\hline & & $\mathrm{S}-1\left(\mathrm{~N} / \mathrm{mm}^{2}\right)$ & $\mathrm{S}-2\left(\mathrm{~N} / \mathrm{mm}^{2}\right)$ & Mean $\left(\mathrm{N} / \mathrm{mm}^{2}\right)$ & & $\mathrm{S}-1\left(\mathrm{~N} / \mathrm{mm}^{2}\right)$ & $\mathrm{S}-2\left(\mathrm{~N} / \mathrm{mm}^{2}\right)$ & Mean $\left(\mathrm{N} / \mathrm{mm}^{2}\right)$ & \\
\hline 1 & 0 & 34.26 & 36.21 & 35.235 & 0.00 & 35.62 & 37.12 & 36.37 & 3.22 \\
\hline 2 & 3 & 34.99 & 35.68 & 35.355 & 0.34 & 36.89 & 35.98 & 36.435 & 3.41 \\
\hline 3 & 6 & 35.68 & 36.12 & 35.9 & 1.89 & 35.46 & 37.42 & 36.44 & 3.42 \\
\hline 4 & 9 & 35.29 & 37.39 & 36.34 & 3.14 & 36.59 & 38.72 & 37.655 & 6.87 \\
\hline 5 & 12 & 35.52 & 35.19 & 35.355 & 0.34 & 36.46 & 36.58 & 36.52 & 3.65 \\
\hline 6 & 15 & 34.67 & 35.28 & 34.97 & -0.75 & 35.91 & 36.96 & 36.435 & 3.41 \\
\hline \multirow[t]{2}{*}{ Sl.no } & \multirow[t]{2}{*}{$\%$ WGP } & \multicolumn{3}{|l|}{$\%$ RSF 1} & $\%$ Increase over & \multicolumn{3}{|l|}{ \% RSF 1.5} & \multirow{2}{*}{$\begin{array}{l}\text { \% Increase over } \\
\text { control speci- } \\
\text { men }\end{array}$} \\
\hline & & $\mathrm{S}-1\left(\mathrm{~N} / \mathrm{mm}^{2}\right)$ & $\mathrm{S}-2\left(\mathrm{~N} / \mathrm{mm}^{2}\right)$ & Mean $\left(\mathrm{N} / \mathrm{mm}^{2}\right)$ & $\begin{array}{l}\text { control speci- } \\
\text { men }\end{array}$ & $\mathrm{S}-1\left(\mathrm{~N} / \mathrm{mm}^{2}\right)$ & $\mathrm{S}-2\left(\mathrm{~N} / \mathrm{mm}^{2}\right)$ & Mean $\left(\mathrm{N} / \mathrm{mm}^{2}\right)$ & \\
\hline 1 & 0 & 36.29 & 37.38 & 36.835 & 4.54 & 34.43 & 36.67 & 35.55 & 0.89 \\
\hline 2 & 3 & 35.49 & 37.62 & 36.555 & 3.75 & 34.89 & 36.35 & 35.62 & 1.09 \\
\hline 3 & 6 & 37.17 & 37.83 & 37.5 & 6.43 & 35.78 & 36.67 & 36.225 & 2.81 \\
\hline 4 & 9 & 39.46 & 39.32 & 39.39 & 11.79 & 37.43 & 37.79 & 37.61 & 6.74 \\
\hline 5 & 12 & 37.31 & 37.42 & 37.365 & 6.05 & 35.23 & 35.31 & 35.27 & 0.10 \\
\hline 6 & 15 & 36.82 & 37.26 & 37.04 & 5.12 & 35.14 & 35.36 & 35.25 & 0.04 \\
\hline
\end{tabular}

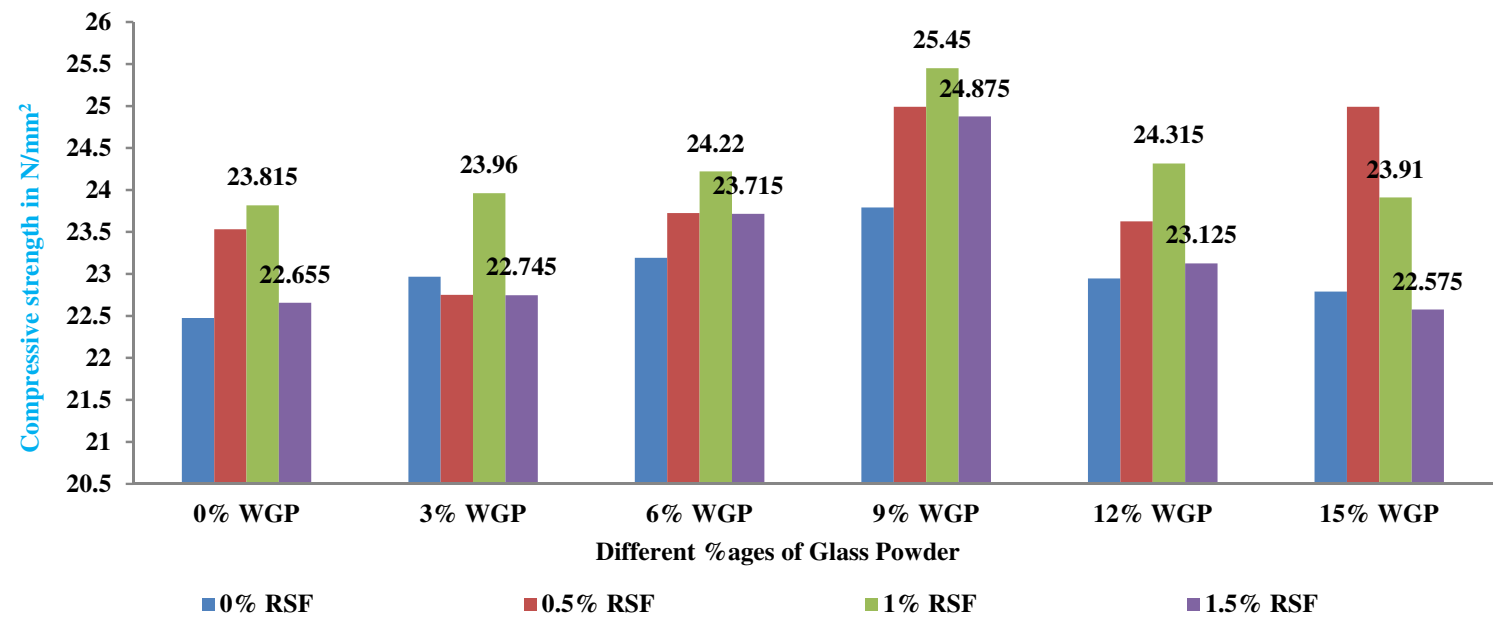

Fig. 8 Cumulative graph showing compressive strength for different \%ages of WGP with different \%age of RSF for 7 days curing

\subsubsection{Graphs depicting for 28 days curing}

The following graphs show the compressive strength results of all concrete mixes composed of different percentages of waste glass powder (WGP) and recycled steel fibers (RSF) after 28 days curing.

\subsection{Discussions}

Compressive strength tests were carried out for every substitutions of waste glass powder and recycled steel fibers, and its results were analyzed and compared with that of control specimen for 28-day curing period presented clearly in Fig. 9. It is seen that maximum value of strength is obtained at $9 \%$ mix of WGP in all cases of inclusion of RSF after 28 days of curing period. The highest value of $39.39 \mathrm{~N} / \mathrm{mm}^{2}$ is observed for $9 \%$ substitution of WGP with $1 \%$ inclusion of RSF showing an increment of $11.79 \%$ over control specimen, and the strength seems to be decreasing with further replacement of WGP for 28 days curing. The lowest value of compressive strength i.e. $35.25 \mathrm{~N} / \mathrm{mm}^{2}$ is produced by a mix with $15 \%$ replacement of WGP with $1.5 \%$ addition of RSF which is slightly higher than control specimen by $0.04 \%$ as shown in the above graph. Therefore, there is a decline in compressive strength with the 


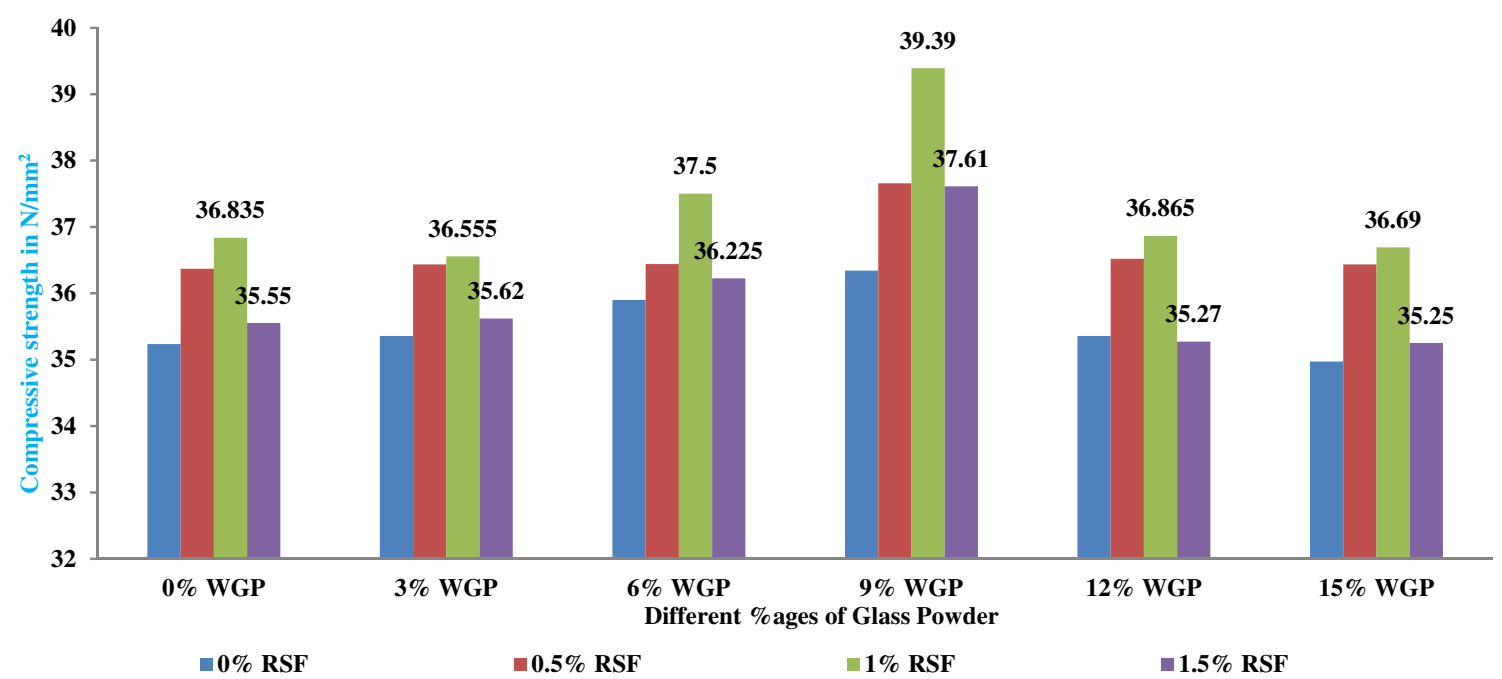

Fig. 9 Cumulative graph showing compressive strength for different \%ages of WGP with different \%age of RSF for 28 days curing

incorporation of WGP higher than $9 \%$ and reinforcement of RSF higher than $1 \%$ after 28 days curing.

\subsection{Flexural strength results}

Beams modified by the incorporation of waste glass powder and recycled steel fibers in the mix are experimented to obtain the flexural strength results for 7 and 28 days curing.

\subsubsection{For 7-day curing period}

The following tables show the flexural strength results of all concrete mixes composed of different percentages of waste glass powder (WGP) and recycled steel fibers (RSF) after 7 days curing (Table 13).

\subsubsection{For 28-day curing period}

The following tables show the flexural strength results of all concrete mixes composed of different percentages of

Table 13 Flexural strength of beams for various replacements of WGP with $0 \%, 0.5 \%, 1 \%, 1.5 \%$ addition of RSF

\begin{tabular}{|c|c|c|c|c|c|c|c|c|c|}
\hline \multirow[t]{2}{*}{ Sl.no } & \multirow[t]{2}{*}{$\%$ WGP } & \multicolumn{3}{|l|}{$\%$ RSF 0} & \multirow{2}{*}{$\begin{array}{l}\text { \% Increase over } \\
\text { control speci- } \\
\text { men }\end{array}$} & \multicolumn{3}{|l|}{ \% RSF 0.5} & \multirow{2}{*}{$\begin{array}{l}\text { \% Increase over } \\
\text { control speci- } \\
\text { men }\end{array}$} \\
\hline & & $\mathrm{S}-1\left(\mathrm{~N} / \mathrm{mm}^{2}\right)$ & $\mathrm{S}-2\left(\mathrm{~N} / \mathrm{mm}^{2}\right)$ & Mean $\left(\mathrm{N} / \mathrm{mm}^{2}\right)$ & & $\mathrm{S}-1\left(\mathrm{~N} / \mathrm{mm}^{2}\right)$ & $\mathrm{S}-2\left(\mathrm{~N} / \mathrm{mm}^{2}\right)$ & Mean $\left(\mathrm{N} / \mathrm{mm}^{2}\right)$ & \\
\hline 1 & 0 & 2.36 & 3.98 & 3.17 & 0.00 & 3.29 & 3.82 & 3.555 & 12.15 \\
\hline 2 & 3 & 2.98 & 3.38 & 3.18 & 0.32 & 3.36 & 3.28 & 3.32 & 4.73 \\
\hline 3 & 6 & 2.76 & 3.67 & 3.215 & 1.42 & 3.46 & 3.89 & 3.675 & 15.93 \\
\hline 4 & 9 & 3.38 & 3.38 & 3.38 & 6.62 & 3.86 & 3.99 & 3.925 & 23.82 \\
\hline 5 & 12 & 2.99 & 3.46 & 3.225 & 1.74 & 3.76 & 3.98 & 3.87 & 22.08 \\
\hline 6 & 15 & 2.89 & 3.46 & 3.175 & 0.16 & 3.75 & 3.72 & 3.735 & 17.82 \\
\hline \multirow[t]{2}{*}{ Sl.no } & \multirow[t]{2}{*}{$\%$ WGP } & \multicolumn{3}{|l|}{ \% RSF 1} & $\%$ Increase over & \multicolumn{3}{|l|}{ \% RSF 1.5} & \multirow{2}{*}{$\begin{array}{l}\% \text { Increase ove } \\
\text { control speci- } \\
\text { men }\end{array}$} \\
\hline & & $\mathrm{S}-1\left(\mathrm{~N} / \mathrm{mm}^{2}\right)$ & $\mathrm{S}-2\left(\mathrm{~N} / \mathrm{mm}^{2}\right)$ & Mean $\left(\mathrm{N} / \mathrm{mm}^{2}\right)$ & men & $\mathrm{S}-1\left(\mathrm{~N} / \mathrm{mm}^{2}\right)$ & $\mathrm{S}-2\left(\mathrm{~N} / \mathrm{mm}^{2}\right)$ & Mean $\left(\mathrm{N} / \mathrm{mm}^{2}\right)$ & \\
\hline 1 & 0 & 3.89 & 3.56 & 3.725 & 17.51 & 3.38 & 3.43 & 3.405 & 7.41 \\
\hline 2 & 3 & 3.89 & 3.67 & 3.78 & 19.24 & 3.34 & 3.69 & 3.515 & 10.88 \\
\hline 3 & 6 & 3.59 & 3.86 & 3.725 & 17.51 & 3.51 & 3.66 & 3.585 & 13.09 \\
\hline 4 & 9 & 4.21 & 4.25 & 4.23 & 33.44 & 3.53 & 3.88 & 3.705 & 16.88 \\
\hline 5 & 12 & 4.19 & 4.08 & 4.135 & 30.44 & 3.54 & 3.26 & 3.4 & 7.26 \\
\hline 6 & 15 & 3.91 & 3.89 & 3.9 & 23.03 & 3.42 & 3.18 & 3.3 & 4.10 \\
\hline
\end{tabular}


waste glass powder (WGP) and recycled steel fibers (RSF) after 28 days curing (Table 14).

\subsubsection{Graphs depicting for 7 days curing}

The following graphs shows the flexural strength results of all concrete mixes composed of different percentages of waste glass powder (WGP) and recycled steel fibers (RSF) after 7 days curing (Table 15).

\subsection{Discussions}

Second set of experiments were conducted to examine the flexural strength characteristics for every concrete mix modified with various replacements of waste glass powder with different percentages of recycled steel fibers after 7-day curing period, and the results are clearly presented in Fig. 10. It is clear from the above graph that there has been an improvement in the flexural strength

Table 14 Flexural strength of beams for various replacements of WGP with $0 \%, 0.5 \%, 1 \%$ and $1.5 \%$ addition of RSF

\begin{tabular}{|c|c|c|c|c|c|c|c|c|c|}
\hline \multirow[t]{2}{*}{ Sl.no } & \multirow[t]{2}{*}{$\%$ WGP } & \multicolumn{3}{|l|}{$\%$ RSF 0} & \multirow{2}{*}{$\begin{array}{l}\text { \% Increase over } \\
\text { control speci- } \\
\text { men }\end{array}$} & \multicolumn{3}{|l|}{ \% RSF 0.5} & \multirow{2}{*}{$\begin{array}{l}\% \text { Increase over } \\
\text { control speci- } \\
\text { men }\end{array}$} \\
\hline & & $\mathrm{S}-1\left(\mathrm{~N} / \mathrm{mm}^{2}\right)$ & $\mathrm{S}-2\left(\mathrm{~N} / \mathrm{mm}^{2}\right)$ & Mean $\left(\mathrm{N} / \mathrm{mm}^{2}\right)$ & & $\mathrm{S}-1\left(\mathrm{~N} / \mathrm{mm}^{2}\right)$ & $\mathrm{S}-2\left(\mathrm{~N} / \mathrm{mm}^{2}\right)$ & Mean $\left(\mathrm{N} / \mathrm{mm}^{2}\right)$ & \\
\hline 1 & 0 & 4.26 & 4.57 & 4.415 & 0.00 & 3.99 & 4.93 & 4.46 & 1.02 \\
\hline 2 & 3 & 4.43 & 4.59 & 4.51 & 2.15 & 4.56 & 4.57 & 4.565 & 3.4 \\
\hline 3 & 6 & 4.72 & 4.62 & 4.67 & 5.78 & 4.69 & 4.91 & 4.80 & 8.72 \\
\hline 4 & 9 & 4.89 & 4.72 & 4.805 & 8.83 & 4.97 & 5.06 & 5.015 & 13.59 \\
\hline 5 & 12 & 4.76 & 4.38 & 4.57 & 3.51 & 4.89 & 4.62 & 4.755 & 7.70 \\
\hline 6 & 15 & 4.56 & 4.29 & 4.425 & 0.23 & 4.79 & 4.51 & 4.65 & 5.32 \\
\hline \multirow[t]{2}{*}{ Sl.no } & \multirow[t]{2}{*}{$\%$ WGP } & \multicolumn{3}{|l|}{ \% RSF 1} & $\%$ Increase over & \multicolumn{3}{|l|}{ \% RSF 1.5} & \multirow{2}{*}{$\begin{array}{l}\% \text { Increase ove } \\
\text { control speci- } \\
\text { men }\end{array}$} \\
\hline & & $\mathrm{S}-1\left(\mathrm{~N} / \mathrm{mm}^{2}\right)$ & $\mathrm{S}-2\left(\mathrm{~N} / \mathrm{mm}^{2}\right)$ & Mean $\left(\mathrm{N} / \mathrm{mm}^{2}\right)$ & $\begin{array}{l}\text { control speci- } \\
\text { men }\end{array}$ & $\mathrm{S}-1\left(\mathrm{~N} / \mathrm{mm}^{2}\right)$ & $\mathrm{S}-2\left(\mathrm{~N} / \mathrm{mm}^{2}\right)$ & Mean $\left(\mathrm{N} / \mathrm{mm}^{2}\right)$ & \\
\hline 1 & 0 & 4.97 & 4.76 & 4.865 & 10.19 & 4.66 & 4.86 & 4.76 & 7.81 \\
\hline 2 & 3 & 4.78 & 4.98 & 4.88 & 10.53 & 4.59 & 4.78 & 4.685 & 6.12 \\
\hline 3 & 6 & 4.93 & 5.02 & 4.975 & 12.68 & 5.29 & 4.32 & 4.805 & 8.83 \\
\hline 4 & 9 & 4.99 & 5.81 & 5.4 & 22.31 & 4.82 & 5.29 & 5.055 & 14.50 \\
\hline 5 & 12 & 4.81 & 5.21 & 5.01 & 13.48 & 4.56 & 4.84 & 4.86 & 10.08 \\
\hline 6 & 15 & 5.21 & 4.68 & 4.945 & 12.00 & 4.68 & 4.78 & 4.73 & 7.13 \\
\hline
\end{tabular}

Table 15 Split tensile strength of cylinders $f$ or various replacements of WGP with $0 \%, 0.5 \%, 1 \%$ and $1.5 \%$ addition of RSF

\begin{tabular}{|c|c|c|c|c|c|c|c|c|c|}
\hline \multirow[t]{2}{*}{ Sl.no } & \multirow[t]{2}{*}{$\%$ WGP } & \multicolumn{3}{|l|}{$\%$ RSF 0} & \multirow{2}{*}{$\begin{array}{l}\% \text { Increase over } \\
\text { control speci- } \\
\text { men }\end{array}$} & \multicolumn{3}{|l|}{ \% RSF 0.5} & \multirow{2}{*}{$\begin{array}{l}\% \text { Increase over } \\
\text { control speci- } \\
\text { men }\end{array}$} \\
\hline & & $\mathrm{S}-1\left(\mathrm{~N} / \mathrm{mm}^{2}\right)$ & $\mathrm{S}-2\left(\mathrm{~N} / \mathrm{mm}^{2}\right)$ & Mean $\left(\mathrm{N} / \mathrm{mm}^{2}\right)$ & & $\mathrm{S}-1\left(\mathrm{~N} / \mathrm{mm}^{2}\right)$ & $\mathrm{S}-2\left(\mathrm{~N} / \mathrm{mm}^{2}\right)$ & Mean $\left(\mathrm{N} / \mathrm{mm}^{2}\right)$ & \\
\hline 1 & 0 & 1.98 & 2.55 & 2.265 & 0.00 & 2.34 & 2.79 & 2.565 & 13.25 \\
\hline 2 & 3 & 1.99 & 2.67 & 2.33 & 2.87 & 2.49 & 2.68 & 2.585 & 14.13 \\
\hline 3 & 6 & 2.21 & 2.84 & 2.525 & 11.48 & 2.61 & 2.61 & 2.61 & 15.23 \\
\hline 4 & 9 & 2.37 & 2.96 & 2.665 & 17.66 & 2.87 & 3.02 & 2.945 & 30.02 \\
\hline 5 & 12 & 2.46 & 2.68 & 2.57 & 13.47 & 2.67 & 2.88 & 2.775 & 22.52 \\
\hline 6 & 15 & 2.37 & 2.49 & 2.43 & 7.28 & 2.53 & 2.97 & 2.75 & 21.41 \\
\hline \multirow[t]{2}{*}{ Sl.no } & \multirow[t]{2}{*}{$\%$ WGP } & \multicolumn{3}{|l|}{ \% RSF 1} & $\%$ Increase over & \multicolumn{3}{|l|}{ \% RSF 1.5} & \multirow{2}{*}{$\begin{array}{l}\% \text { Increase ove } \\
\text { control speci- } \\
\text { men }\end{array}$} \\
\hline & & $\mathrm{S}-1\left(\mathrm{~N} / \mathrm{mm}^{2}\right)$ & $\mathrm{S}-2\left(\mathrm{~N} / \mathrm{mm}^{2}\right)$ & Mean $\left(\mathrm{N} / \mathrm{mm}^{2}\right)$ & men & $\mathrm{S}-1\left(\mathrm{~N} / \mathrm{mm}^{2}\right)$ & $\mathrm{S}-2\left(\mathrm{~N} / \mathrm{mm}^{2}\right)$ & Mean $\left(\mathrm{N} / \mathrm{mm}^{2}\right)$ & \\
\hline 1 & 0 & 2.76 & 2.98 & 2.87 & 26.71 & 2.18 & 2.51 & 2.345 & 3.53 \\
\hline 2 & 3 & 2.79 & 2.98 & 2.885 & 27.37 & 2.31 & 2.64 & 2.475 & 9.27 \\
\hline 3 & 6 & 2.81 & 2.98 & 2.895 & 27.81 & 2.44 & 2.58 & 2.51 & 10.82 \\
\hline 4 & 9 & 3.12 & 3.56 & 3.34 & 47.46 & 2.51 & 3.03 & 2.77 & 22.30 \\
\hline 5 & 12 & 2.79 & 3.26 & 3.025 & 33.55 & 2.44 & 2.68 & 2.56 & 13.02 \\
\hline 6 & 15 & 2.88 & 2.98 & 2.93 & 29.36 & 2.34 & 2.58 & 2.46 & 8.61 \\
\hline
\end{tabular}




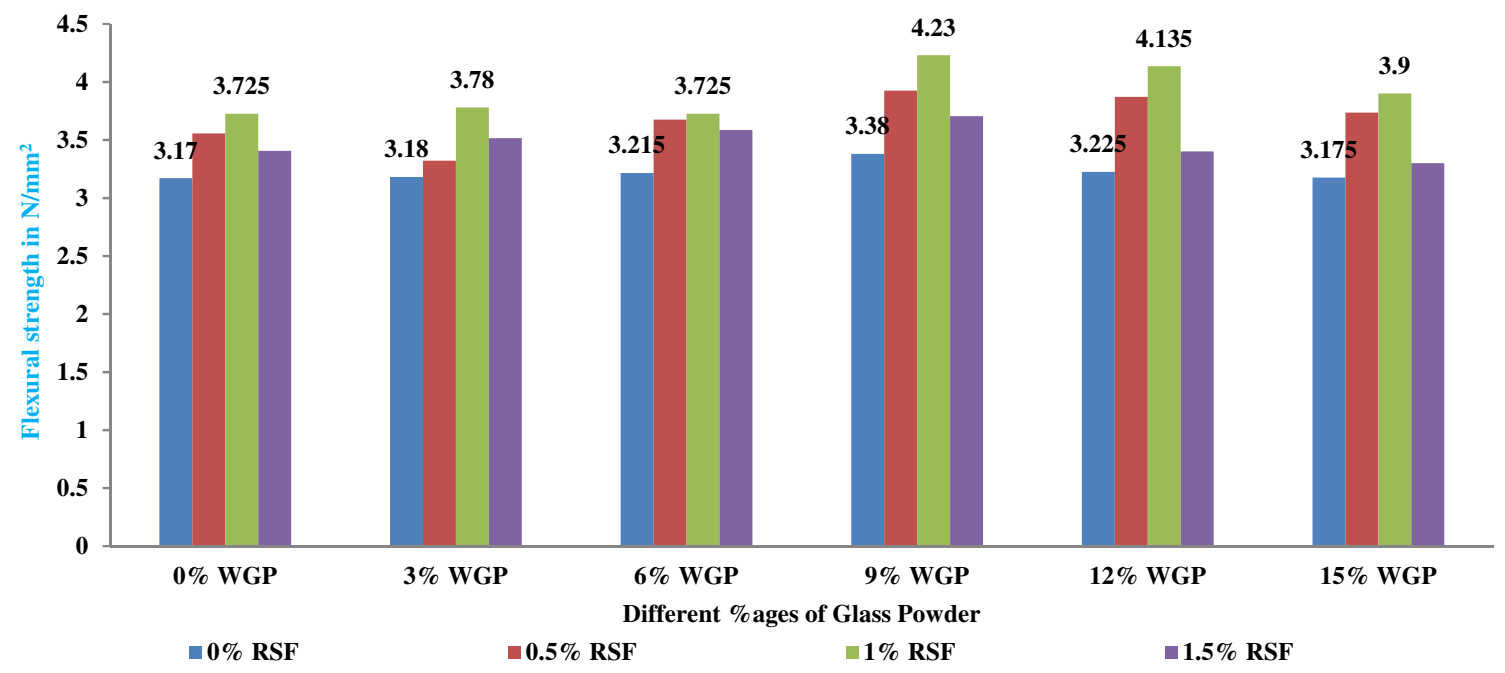

Fig. 10 Cumulative graph showing flexural strength for different \%ages of WGP with different \%age of RSF for 7 days curing

results with the introduction of steel fibers, especially for $1 \%$ addition of RSF. The peak value of $4.23 \mathrm{~N} / \mathrm{mm}^{2}$ flexural strength is reported by concrete mix composed of $9 \%$ substitution of WGP and 1\% inclusion of RSF which showed an increase of $33.44 \%$ over ordinary concrete. The lowest value of $3.175 \mathrm{~N} / \mathrm{mm}^{2}$ is seen for $15 \%$ substitution of WGP mix with $0 \%$ addition of RSF which is little greater than the strength of ordinary concrete by $0.16 \%$. Hence, it is clearly evident that flexural performance of concrete improved considerably with the higher percentage of inclusions of RSF by volume, but the flexural strength showed a decrement with higher replacements levels of WGP above $9 \%$.

\subsubsection{Graphs depicting for 28 days curing}

The following graphs show the flexural strength results of all concrete mixes composed of different percentages of waste glass powder (WGP) and recycled steel fibers (RSF) after 28 days curing (Table 16).

\subsection{Discussions}

Flexural strength tests were performed for every mix proportion modified with waste glass powder and recycled steel fibers after 28-day curing period, and its results were studied and analyzed as portrayed in Fig. 11. It is very much evident from the graph that $t$ maximum value of strength is obtained at $9 \%$ mix of WGP in all cases of inclusion of RSF for 28 days of curing period. The highest value of $5.4 \mathrm{~N} / \mathrm{mm}^{2}$ is exhibited by a concrete mix combined with $9 \%$ replacement of WGP with $1 \%$ inclusion of RSF showing an increment of $22.31 \%$ over control specimen, and the value seems to be decreasing with further replacement of WGP for 28 days curing. A concrete mix composed of $15 \%$ substitution of WGP and $0 \%$ addition of RSF showed the minimum value of $4.425 \mathrm{~N} / \mathrm{mm}^{2}$ with a little increment over control specimen by $0.23 \%$. Therefore, the above results report that the flexural performance of concrete increases with the increase in the addition of RSF by volume of concrete but decreases with further addition of WGP above $9 \%$ after 28 days curing.

\subsection{Split tensile strength results}

Cylinders casted with the compositions of waste glass powder and recycled steel fibers in the mix are tested to obtain the split tensile strength results for 7 and 28 days curing.

\subsubsection{For 7-day curing period}

The following tables show the split tensile strength results of all concrete mixes composed of different percentages of waste glass powder (WGP) and recycled steel fibers (RSF) after 7 days curing.

\subsubsection{For 28-day curing period}

The following tables show the split tensile strength results of all concrete mixes composed of different percentages of waste glass powder (WGP) and recycled steel fibers (RSF) after 28 days curing.

\subsubsection{Graphs depicting for 7 days curing}

The following graphs show the split tensile strength results of all concrete mixes composed of different percentages of 
Table 16 Split tensile strength of cylinders for various replacements of WGP with $0 \%, 0.5 \%, 1 \%$ and $1.5 \%$ addition of RSF

\begin{tabular}{|c|c|c|c|c|c|c|c|c|c|}
\hline \multirow[t]{2}{*}{ Sl.no } & \multirow[t]{2}{*}{$\%$ WGP } & \multicolumn{3}{|l|}{$\%$ RSF 0} & \multirow{2}{*}{$\begin{array}{l}\% \text { Increase over } \\
\text { control speci- } \\
\text { men }\end{array}$} & \multicolumn{3}{|l|}{ \% RSF 0.5} & \multirow{2}{*}{$\begin{array}{l}\text { \% Increase over } \\
\text { control speci- } \\
\text { men }\end{array}$} \\
\hline & & $\mathrm{S}-1\left(\mathrm{~N} / \mathrm{mm}^{2}\right)$ & $\mathrm{S}-2\left(\mathrm{~N} / \mathrm{mm}^{2}\right)$ & Mean $\left(\mathrm{N} / \mathrm{mm}^{2}\right)$ & & $\mathrm{S}-1\left(\mathrm{~N} / \mathrm{mm}^{2}\right)$ & $\mathrm{S}-2\left(\mathrm{~N} / \mathrm{mm}^{2}\right)$ & Mean $\left(\mathrm{N} / \mathrm{mm}^{2}\right)$ & \\
\hline 1 & 0 & 3.09 & 3.38 & 3.235 & 0.00 & 3.39 & 3.84 & 3.615 & 11.75 \\
\hline 2 & 3 & 2.98 & 3.64 & 3.31 & 2.32 & 3.47 & 3.59 & 3.53 & 9.12 \\
\hline 3 & 6 & 3.17 & 3.49 & 3.33 & 2.94 & 3.46 & 3.89 & 3.675 & 13.60 \\
\hline 4 & 9 & 3.39 & 3.57 & 3.48 & 7.57 & 3.75 & 3.98 & 3.865 & 19.47 \\
\hline 5 & 12 & 3.29 & 3.43 & 3.36 & 3.86 & 3.88 & 3.68 & 3.78 & 16.85 \\
\hline 6 & 15 & 3.46 & 3.28 & 3.37 & 4.17 & 3.79 & 3.59 & 3.69 & 14.06 \\
\hline \multirow[t]{2}{*}{ Sl.no } & \multirow[t]{2}{*}{$\%$ WGP } & \multicolumn{3}{|l|}{ \% RSF 1} & $\%$ Increase over & \multicolumn{3}{|l|}{ \% RSF 1.5} & \multirow{2}{*}{$\begin{array}{l}\text { \% Increase over } \\
\text { control speci- } \\
\text { men }\end{array}$} \\
\hline & & $\mathrm{S}-1\left(\mathrm{~N} / \mathrm{mm}^{2}\right)$ & $\mathrm{S}-2\left(\mathrm{~N} / \mathrm{mm}^{2}\right)$ & Mean $\left(\mathrm{N} / \mathrm{mm}^{2}\right)$ & $\begin{array}{l}\text { control specl- } \\
\text { men }\end{array}$ & $\mathrm{S}-1\left(\mathrm{~N} / \mathrm{mm}^{2}\right)$ & $\mathrm{S}-2\left(\mathrm{~N} / \mathrm{mm}^{2}\right)$ & Mean $\left(\mathrm{N} / \mathrm{mm}^{2}\right)$ & \\
\hline 1 & 0 & 3.79 & 3.92 & 3.855 & 19.17 & 3.33 & 3.51 & 3.42 & 5.72 \\
\hline 2 & 3 & 3.66 & 4.12 & 3.89 & 20.25 & 3.39 & 3.53 & 3.46 & 6.96 \\
\hline 3 & 6 & 3.81 & 4.23 & 4.02 & 24.27 & 3.09 & 4.08 & 3.585 & 10.82 \\
\hline 4 & 9 & 4.29 & 4.68 & 4.485 & 38.64 & 3.69 & 4.06 & 3.875 & 19.78 \\
\hline 5 & 12 & 4.59 & 3.71 & 4.15 & 28.28 & 3.52 & 3.76 & 3.64 & 12.52 \\
\hline 6 & 15 & 3.92 & 3.81 & 3.865 & 19.47 & 3.41 & 3.65 & 3.53 & 9.12 \\
\hline
\end{tabular}

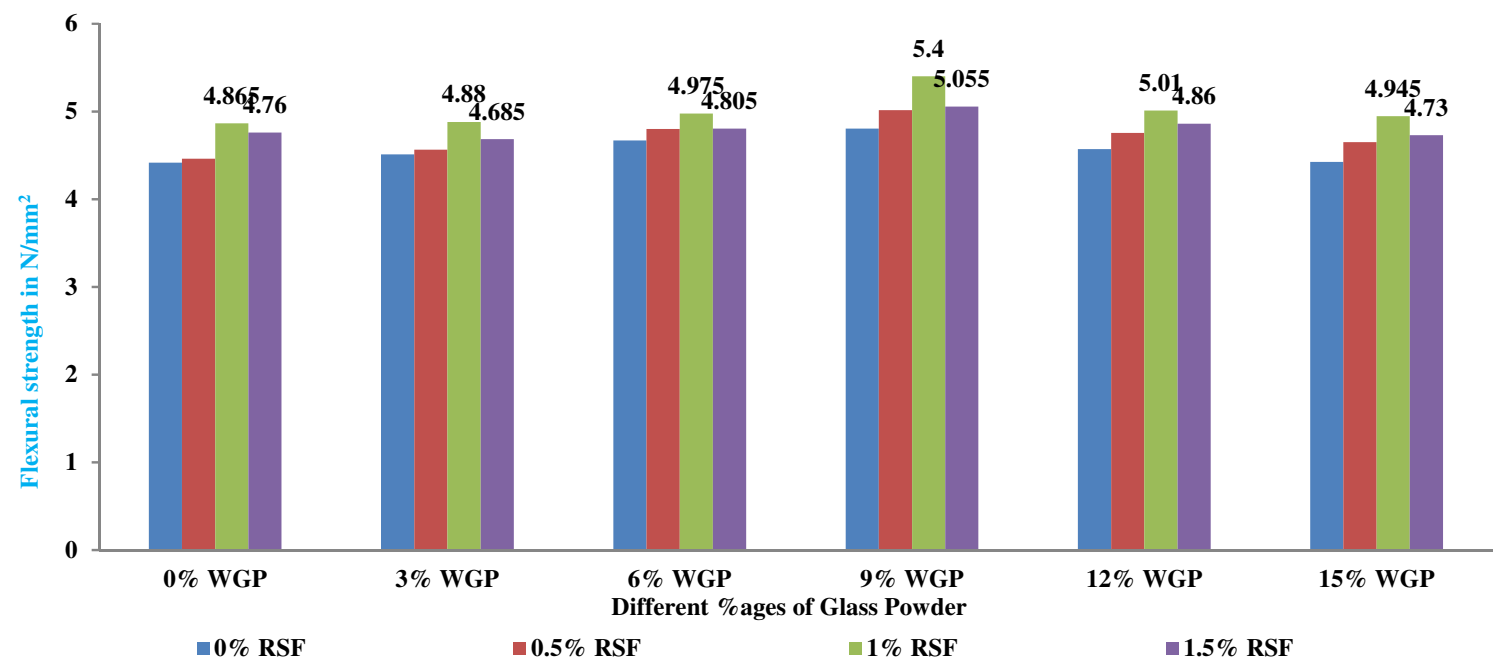

Fig. 11 Cumulative graph showing flexural strength for different \%ages of WGP with different \%age of RSF for 28 days curing

waste glass powder (WGP) and recycled steel fibers (RSF) after 7 days curing.

\subsection{Discussions}

Split tensile strength results of cylinders were examined for all mix proportions combined with various substitutions of waste glass powder and various percentage inclusion of recycled steel fibers, and the tests were correlated and studied with the results obtained for ordinary concrete for 7-day curing period as shown in Fig. 12. Addition of WGP and RSF has impacted a significant rise in the split tensile strength till 9\% replacement of WGP and 1\% RSF, and the results started to decline with further addition of WGP. The highest split tensile strength of $3.34 \mathrm{~N} / \mathrm{mm}^{2}$ is exerted by a concrete mix composed of $9 \%$ substitution of WGP with $1 \%$ inclusion of RSF with an increment of $47.46 \%$ over ordinary concrete. The least value of $2.43 \mathrm{~N} / \mathrm{mm}^{2}$ is attained by a concrete mix with $15 \%$ substitution of WGP and $0 \%$ inclusion of RSF which is slightly greater than control concrete by $7.28 \%$. Henceforth, concrete mixes showed higher split tensile performance with increased amounts of RSF by volume but declined for further replacement levels of WGP above $9 \%$. 


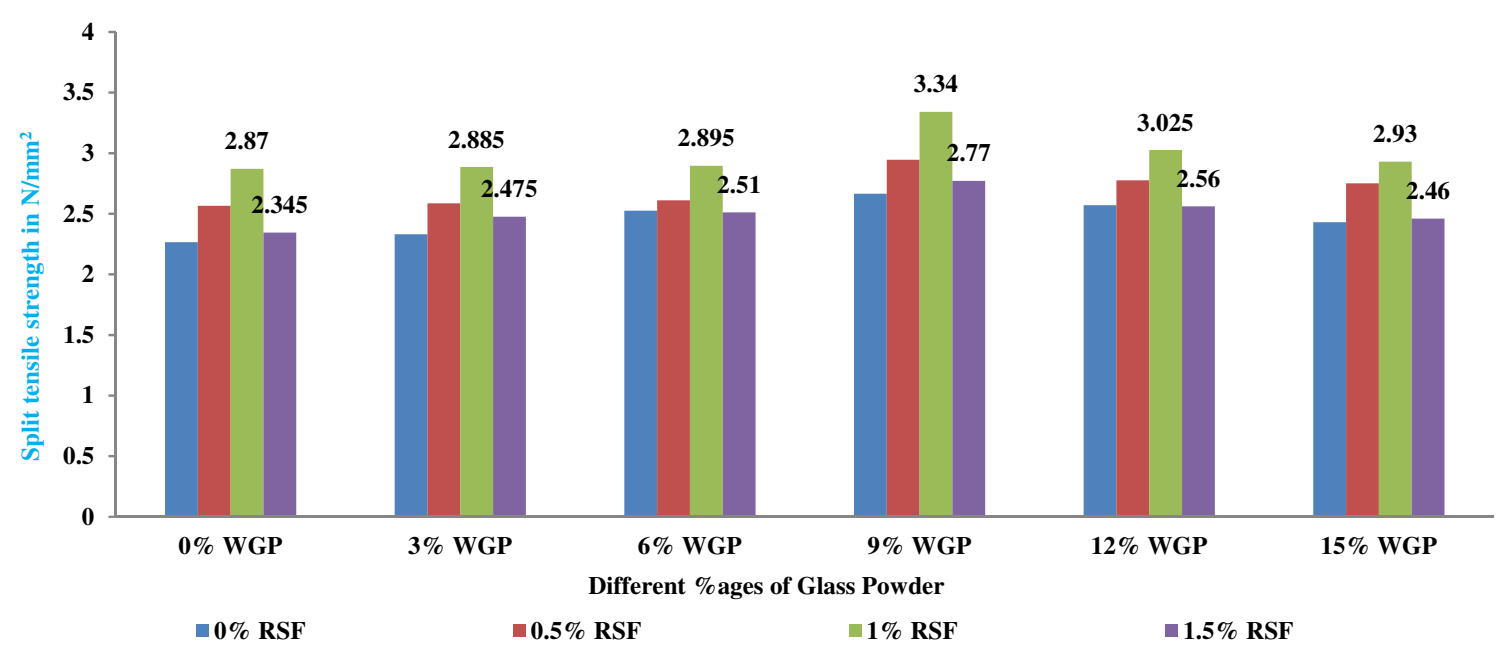

Fig. 12 Cumulative graph showing split tensile strength for different \%ages of WGP with different \%age of RSF for 7 days curing

\subsubsection{Graphs depicting for 28 days curing}

The following graphs show the split tensile strength results of all concrete mixes composed of different percentages of waste glass powder (WGP) and recycled steel fibers (RSF) after 28 days curing.

\subsection{Discussions}

Split tensile strength tests were conducted for mix proportion of concrete, and its results were executed and investigated as shown in Fig. 13 after a curing period of 28 days. It is seen that maximum value of strength is obtained at
$9 \%$ mix of WGP in all cases of addition of RSF for 28 days of curing period. A concrete mix combined with $9 \%$ substitution of WGP and $1 \%$ inclusion of RSF exhibited the maximum strength of $4.485 \mathrm{~N} / \mathrm{mm}^{2}$ indicating an increment of $38.64 \%$ over control specimen and strength decreased with further replacements of WGP, i.e., $12 \%$ and $15 \%$. The lowest value of split tensile strength, i.e., $3.37 \mathrm{~N} / \mathrm{mm}^{2}$, is given a concrete mix combined with 15\% WGP and $0 \%$ inclusion of RSF that reported a little increment of $4.17 \%$ over control specimen. The above results indicate that the split tensile strength improved significantly with higher reinforcements of RSF till $1.5 \%$ by volume, but it declines with further substitutions of WGP above $9 \%$ after 28 days.

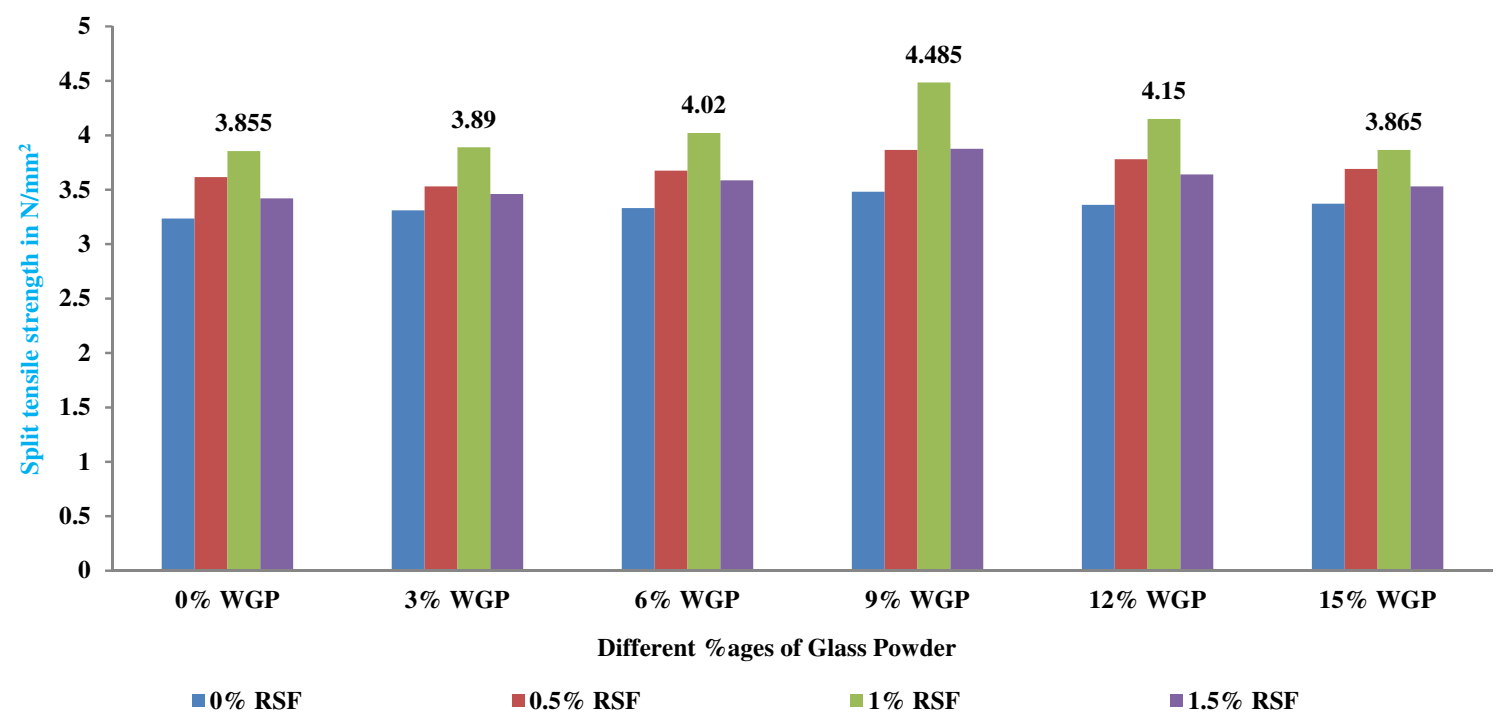

Fig. 13 Cumulative graph showing split tensile strength for different \%ages of WGP with different \%age of RSF for 28 days curing 


\section{Conclusions}

The following are the conclusions extracted from the results and discussions obtained from the experiments.

a. The utilization of waste glass powder and recycled steel fibers in concrete mixes has resulted in the increased compressive, flexural and split tensile strength for both 7 days and 28 days curing.

b. Compressive strength showed a gradual increment till $9 \%$ replacement of waste glass powder and later decreased with further replacement of $12 \%$ and $15 \%$ which indicates that $9 \%$ mix of waste glass powder exhibited the best overall compressive performance.

c. All concrete mixes with $9 \%$ replacement level of waste glass powder reinforced with four different fractions of recycled steel fibers produced maximum compressive strength results but among all a mix of $9 \%$ WGP with $1 \%$ inclusion of RSF exerted a maximum compressive strength with an increment of $11.79 \%$ over control specimen for 28-day curing period.

d. Utilization of waste glass powder above $9 \%$ substitution and RSF above $1 \%$ by volume is not recommendable to achieve maximum compressive strength.

e. Flexural and split tensile strength of all concrete mixes improved significantly with the addition of higher fractions of recycled steel fibers, i.e., $0.5 \%, 1 \%$ and $1.5 \%$, but $1 \%$ inclusion of recycled steel fibers exhibited higher performance in terms of flexural, split tensile as well as compressive strength also.

f. All concrete mixes with $0 \%$ inclusion of recycled steel fibers exhibited the least flexural strength that increased gradually with further inclusion of higher fractions of steel fibers, and a concrete mix with $1 \%$ inclusion of RSF and 9\% WGP showed the best overall performance in terms of flexural strength with a rise in strength by $22.31 \%$ over control specimen after 28 days of curing period.

g. Utilization of waste glass powder above $9 \%$ substitution is not preferable to obtain higher flexural strength, but the higher amount of RSF by volume contributes in attaining higher flexural strength.

h. All concrete mixes with $0 \%$ inclusion of recycled steel fibers exhibited the least split tensile that increased gradually with further inclusion of higher fractions of steel fibers, and a concrete mix with $1 \%$ inclusion of RSF and 9\% WGP reported the highest split tensile strength with an increment of $38.64 \%$ over control specimen after 28 days of curing period.

i. Incorporation of waste glass powder above $9 \%$ replacement level is not commendable to obtain higher split tensile strength, but the higher amount of RSF up to $1.5 \%$ by volume is highly recommendable to achieve higher split tensile strength.

\section{Compliance with ethical standards}

Conflict of interest The author states that there is no conflict of interest.

Open Access This article is licensed under a Creative Commons Attribution 4.0 International License, which permits use, sharing, adaptation, distribution and reproduction in any medium or format, as long as you give appropriate credit to the original author(s) and the source, provide a link to the Creative Commons licence, and indicate if changes were made. The images or other third party material in this article are included in the article's Creative Commons licence, unless indicated otherwise in a credit line to the material. If material is not included in the article's Creative Commons licence and your intended use is not permitted by statutory regulation or exceeds the permitted use, you will need to obtain permission directly from the copyright holder. To view a copy of this licence, visit http://creativecommons .org/licenses/by/4.0/.

\section{References}

1. Simalti A, Singh AP (2021) Comparative study on performance of manufactured steel fiber and shredded tire recycled steel fiber reinforced self-consolidating concrete. Constr Build Mater. https ://doi.org/10.1016/j.conbuildmat.2020.121102

2. Isa MN, Pilakoutas K, Guadagnini M, Angelakopoulos H (2020) Mechanical performance of affordable and eco-efficient ultrahigh performance concrete (UHPC) containing recycled tyre steel fibers. Constr Build Mater. https://doi.org/10.1016/j.conbu ildmat.2020.119272

3. Zhong H, Zhang M (2020) Experimental study on engineering properties of concrete reinforced with hybrid recycled tyre steel and polypropylene fibers. J Clean Prod. https://doi. org/10.1016/j.jclepro.2020.120914

4. Samindi SM, Samarakoon MK, Ruben P, Pedersen JW, Evangelista $L$ (2019) Mechanical properties of concrete made of steel fibers from tire waste. Caste Stud Constr Mater. https://doi. org/10.1016/j.cscm.2019.e00259

5. Gul S, Naseer S (2019) Concrete containing recycled rubber steel fiber. Procedia Struct Integr 18:101-107. https://doi. org/10.1016/j.prostr.2019.08.144

6. Liew KM, Akbar A (2020) The recent progress of recycled steel fiber reinforced concrete. Constr Build Mater. https://doi. org/10.1016/j.conbuildmat.2019.117232

7. Belouadah M, Rahmouni ZEA, Tebbal N (2019) Experimental characterization of ordinary concretes obtained by adding construction waste (glass, marble). Procedia Comput Sci 158:153-162

8. Belouadah M, Rahmouni ZEA, Tebbal N (2019) Influence of the addition of glass powder and marble powder on the physical and mechanical behavior of composite cement. Procedia Comput Sci 158:366-375

9. Rahma A, El Naber N, Ismail SI (2017) Effect of glass powder on the compression strength and the workability of concrete. Cogent Eng 4(1):1373415 
10. Morsli H, Rabah C, Molez L, Diouri A (2018) Effect of glass addition on the properties of cements (CEMI). J Build Mater Struct 5(1):65-73

11. Patel D, Tiwari RP, Shrivastava R, Yadav RK (2019) Effective utilization of waste glass powder as the substitution of cement in making paste and mortar. Constr Build Mater 199:406-415. https://doi.org/10.1016/j.conbuildmat.2018.12.017

12. Asokan P, Osmani M (2010) Improvement of the mechanical properties of glass fibre reinforced plastic waste powder filled concrete. Constr Build Mater 24:448-460. https://doi. org/10.1016/j.conbuildmat.2009.10.017

13. Raharjo D, Subakti AT (2013) Mixed concrete optimization using fly ash, silica fume and iron slag on SSC's compressive strength. Procedia Eng 54:827-839. https://doi.org/10.1016/j.proen g.2013.03.076

14. Du H, Tan KH (2014) Waste Glass powder as cement replacement in concrete. J Adv Concr Technol 12:468-477. https://doi. org/10.3151/jact.12.468

15. Kamali M, Ghahramaninezhad A (2015) Effect of glass powders on the mechanical and durability properties of cementitious materials. Constr Build Mater 98:407-416. https://doi. org/10.1016/j.conbuildmat.2015.06.010

16. Islam GMS, Rahman MdH, Kazi N (2016) Waste glass powder as partial replacement of cement for sustainable concrete practice. Int J Sustain Built Environ 6:37-44. https://doi.org/10.1016/j. ijsbe.2016.10.005

17. Harbec D, Zidol A, Hamou AT, Hofer FG (2017) Mechanical and durability properties of high performance glass fume concrete and mortars. Constr Build Mater 134:142-156. https://doi. org/10.1016/j.conbuildmat.2016.12.018

18. Narayanan A, Shanmugasundaram P (2017) An experimental investigation on fly ash based geopolymer mortar under different curing regime for thermal analysis. Energy Build 138:539545. https://doi.org/10.1016/j.enbuild.2016.12.079

19. Ramakrishnan K, Pugazhmani G, Sripragadeesh R, Muthu D, Venkatasubramanian C (2017) Experimental study on the mechanical and durability properties of concrete with waste glass powder and ground granulated blast furnace slag as supplementary cementitious materials. Constr Build Mater 156:739-749. https ://doi.org/10.1016/j.conbuildmat.2017.08.183

20. Kumar S, Nagar B (2018) Effects of waste glass powder on compressive strength of concrete. Int J Trend Sci Res Dev 1:24566470. https://doi.org/10.13140/RG.2.2.19255.37284

21. Elaqra HA, Al-Afghany MJ, Abo-Hasseira AB, Elmasry IH, Tabasi AM, Alwan MD (2019) Effect of immersion time of glass powder on mechanical properties of concrete contained glass powder as cement replacement. Constr Build Mater 206:674-682. https ://doi.org/10.1016/j.conbuildmat.2019.02.110

22. Elaqra HA, Haloub MAA (2019) Effect of new mixing method of glass powder as cement replacement on mechanical behaviour of concrete. Constr Build Mater 203:75-82. https://doi. org/10.1016/j.conbuildmat.2019.01.077
23. Ramdani S, Guettala A, Benmalek ML (2019) Physical and mechanical performance of concrete made with waste rubber aggregate, glass powder and silica sand powder. J Build Mater 21:302-311. https://doi.org/10.1016/j.jobe.2018.11.003

24. Pandurangan K, Thennavan M, Muthadhi A (2018) Studies on effect of source of Fly ash on the bond strength of geopolymer concrete. Mater Today Proc 5:12725-12733. https://doi. org/10.1016/j.matpr.2018.02.256

25. Jain KL, Sancheti G, Gupta LK (2020) Durability performance of waste granite and glass powder added concrete. Constr Build Mater. https://doi.org/10.1016/j.conbuildmat.2020.119075

26. Gokulnath V, Ramesh B, Suvesha S (2020) Influence on flexural properties of glass powder in self compacting concrete. Mater Today Proc 22:788-792. https://doi.org/10.1016/j.matpr .2019.10.153

27. Khan QS, Sheikh MN, McCarthy TJ, Robati M, Allen M (2019) Experimental investigation on foam concrete without and with recycled glass powder: a sustainable solution for future construction. Constr Build Mater 201:369-379. https://doi. org/10.1016/j.conbuildmat.2018.12.178

28. He Z, Zhan P, Du S, Liu B, Yuan W (2019) Creep behaviour of concrete containing glass powder. Compos B Eng 166:13-20. https://doi.org/10.1016/j.compositesb.2018.11.133

29. Hama SM, Mahmoud AS, Yassen MM (2019) Flexural behaviour of reinforced concrete beam incorporating waste glass powder. Structures 20:510-518. https://doi.org/10.1016/j.istru c.2019.05.012

30. Rehman S, Iqbal A, A., (2018) Combined influence of glass powder and granular steel slag on fresh and mechanical properties of self compacting concrete. Constr Build Mater 178:153-160. https://doi.org/10.1016/j.conbuildmat.2018.05.148

31. Bostanci SC (2020) Use of waste marble dust and recycled glass for sustainable concrete production. J Clean Prod. https://doi. org/10.1016/j.jclepro.2019.119785

32. Yasouj SEM, Ghaderi A (2020) Experimental investigation of waste glass powder, basalt fibre and carbon nanotube on the mechanical properties of concrete. Constr Build Mater https:// doi.org/10.1016/j.conbuildmat.2020.119115

33. Wang C, Wang H (2017) Assessment of compressive strength of recycled waste $L C D$ glass concrete using ultrasonic pulse velocity. Constr Bulid Mater 137:345-353. https://doi.org/10.1016/j. conbuildmat.2017.01.117

34. Aliabdo AA, Elmoaty AM, Aboshama AY (2016) Utilization of waste glass powder in the production of cement and concrete. Constr Build Mater 124:866-877. https://doi.org/10.1016/j. conbuildmat.2016.08.016

Publisher's Note Springer Nature remains neutral with regard to jurisdictional claims in published maps and institutional affiliations. 